\title{
ÉTUDES
}

\author{
ADITIA GUNAWAN ${ }^{1}$
}

\section{Textiles in Old-Sundanese Texts}

\section{Introduction}

Once upon a time Dayang Sumbi was having a wonderful time weaving. Her taropong, that is, a bamboo tool for rolling yarn, fell from her hands. So frail was she that she joked: if a woman would pick up that taropong for her, she would make her her sister, and if a man would do so, she would surely make him her husband. Si Tumang, her loyal dog, heard that promise. With enthusiasm he picked up the taropong, presenting it to Dayang Sumbi while sitting in front of her and staring at her intently. Dayang Sumbi regretted her words. But the oath could not be unsaid. Dayang Sumbi finally married Tumang and they had a son, Sang Kuriang.

1. Staff member of the National Library of Indonesia (Jakarta), PhD student at the EPHE (Paris), associate member of the Centre Asie du Sud-Est (CASE, Paris), aditia. gunawan@efeo.net. I wish to thank Mr. Mamat Sasmita who has given valuable input on this article, Jirrí Jákl who has given helpful comments on previous drafts, Ida Bagus Komang Sudarma who has shared data from Bali, Henri Chambert-Loir (Archipel) who gave not only encouragement but also precious comments, and finally Marine Schoettel as well as an anonymous reviewer of Archipel for their valuable remarks. However, I also wish to thank Wayan Jarrah Sastrawan, who helped translate this article into English with great care. And I wish to thank especially Arlo Griffiths (EFEO) who corrected and gave many valuable comments to the last versions of the article. This article is being published as my first contribution to the project DHARMA "The Domestication of 'Hindu' Asceticism and the Religious Making of South and Southeast Asia," funded by the European Research Council (ERC) under the European Union's Horizon 2020 research and innovation programme (grant agreement no 809994). 
This famous Sundanese legend of Sang Kuriang has several different versions. Nevertheless, however diverse the characters' names and plot variations may seem, in general this legend contains the same story. Some version of it was recalled by Bujangga Manik, ${ }^{2}$ a wandering ascetic of the 15th century, when he visited Mount Patégéng (BM, 11. 1336-1342):

Sadatang ka kabuyutan, meu(n)tas di Cisaunggalah, leumpang aing ka baratkeun, datang ka bukit Patégéng, sakakala Sang Kuriang, masa dek nyitu Citarum,

burung tembey kasiangan.
Upon reaching the sacred place, crossing at [the river] Cisaunggalah, I travelled to the west, arriving at Mount Patégéng, the memorial of Sang Kuriang, of the time when he would dam [the river] Citarum, but failed because of the arrival of day.

If the story of Sang Kuriang had become legend in the 15th century, it can be said that weaving traditions were present in the land of Sunda long before that. Another Sundanese legend, namely that of Nini Anteh (antéh itself has the connotation of making yarn), figures a child and a cat who climb a tree that soars up to the moon. For Sundanese people who believe it, the black shadows on the moon during a full moon are the shadows of Nini Antéh, the small child and the cat who are making yarn.

Besides what is reflected in various folk tales or legends, we find many idioms and Sundanese proverbs associated with weaving traditions, such as: ngaheuyeuk dayeuh ngolah nagara ("weaving the city, managing the state"), which refers to governance; paheuyeuk-heuyeuk lengeun ("weaving each other's hands"), which refers to solidarity; bobo sapanon carang sapakan ("a broken mesh hole, a missing weft thread"), which is very commonly pronounced in a concluding speech as an apology for the speaker's imperfections of expression.

The cultural practice underlying such idioms is now a thing of the past. Traditional weaving has perished in the Sundanese-speaking area, except in the region of Kanékés (Baduy), in South Banten. The most complete and perhaps final ethnographic descriptions were published by C.M. Pleyte in 1912 and by Jasper \& Pirngadie in the same year, when textile traditions were still alive in the Priangan region. Their research regarding textile production in western Java at the beginning of the 20th century is quite detailed and useful

2. For convenience, the author has standardised the spelling of Old Sundanese based on spelling in Modern Sundanese, outlined in the book Palanggeran Éjahan Basa Sunda (2008). In small cases, such as specific readings on manuscripts and inscriptions, the author uses the Transliteration Guide of the project DHARMA (Balogh et al., 2019). 


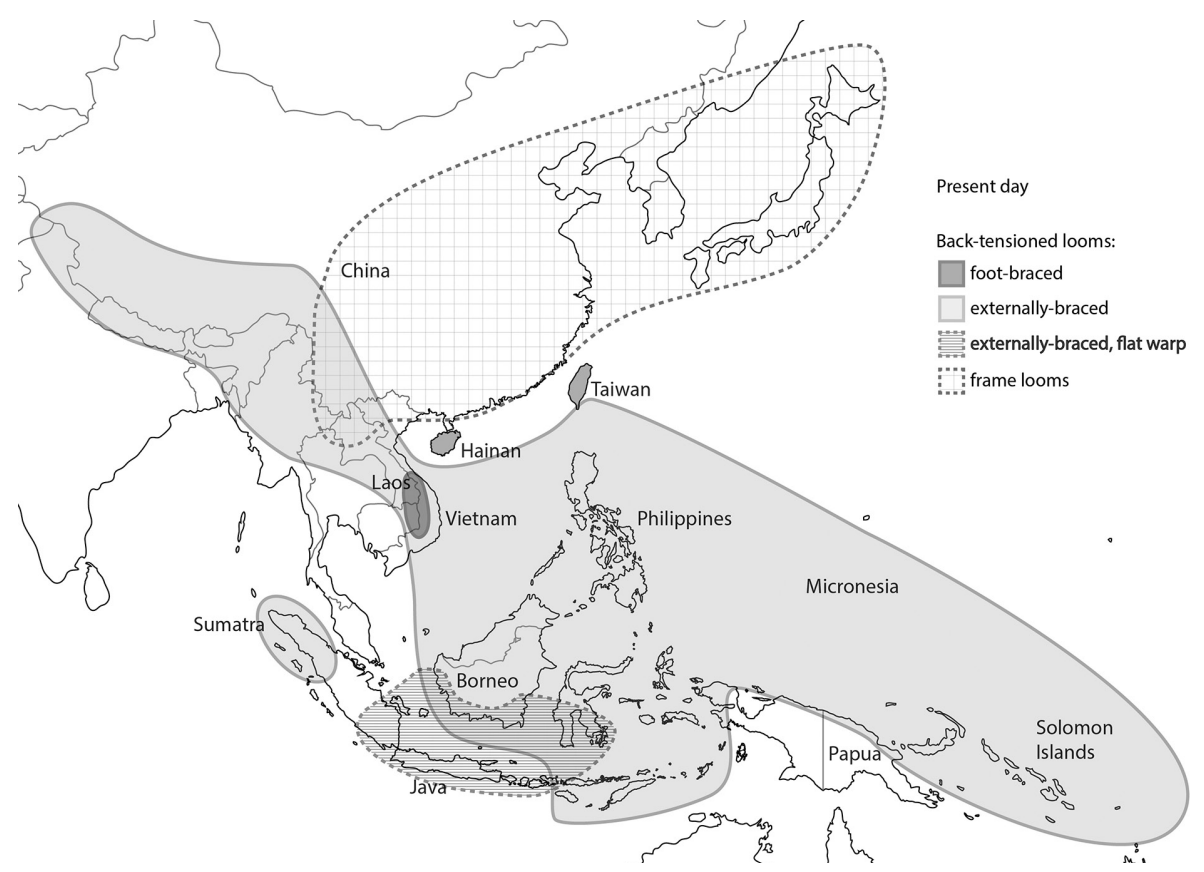

Fig. 1 - Distribution of types of loom in Asia in the present day. (Source: Buckley 2017)

for understanding the technology of production of woven fabrics, including tools, motifs and symbolic aspects. However, no attempt was made by those scholars to trace the history of this tradition in the Sunda region back to the precolonial period. In 2015, Mamat Sasmita published an article about decorative styles in this region based on an Old-Sundanese text, the Sang Hyang Siksa Kandang Karesian. The study is useful even though it does not describe the full breadth of activities and traditions related to weaving.

The present article, which has been inspired by the work of Wisseman Christie (1993) regarding texts and textiles in what she calls 'Medieval Java' (i.e., from the 9 th through the 12 th century), aims to fill some of the gaps in research so far. It is important to compare early Sundanese textile culture with what was practiced in the Javanese-speaking area during the period covered by the Old Sundanese sources (ca. 14th-17th century), considering that both regions share the same basic weaving traditions, especially in terms of technique. According to the classification of Buckley (2017, see fig. 1), West Java is included in the areas that were strongly influenced by Indianisation which share characteristic similarities in their weaving traditions: the first feature relates to the kind of loom that this scholar denotes as an externallybraced loom with flat warp and reed, or a loom whose warp is flat while the 


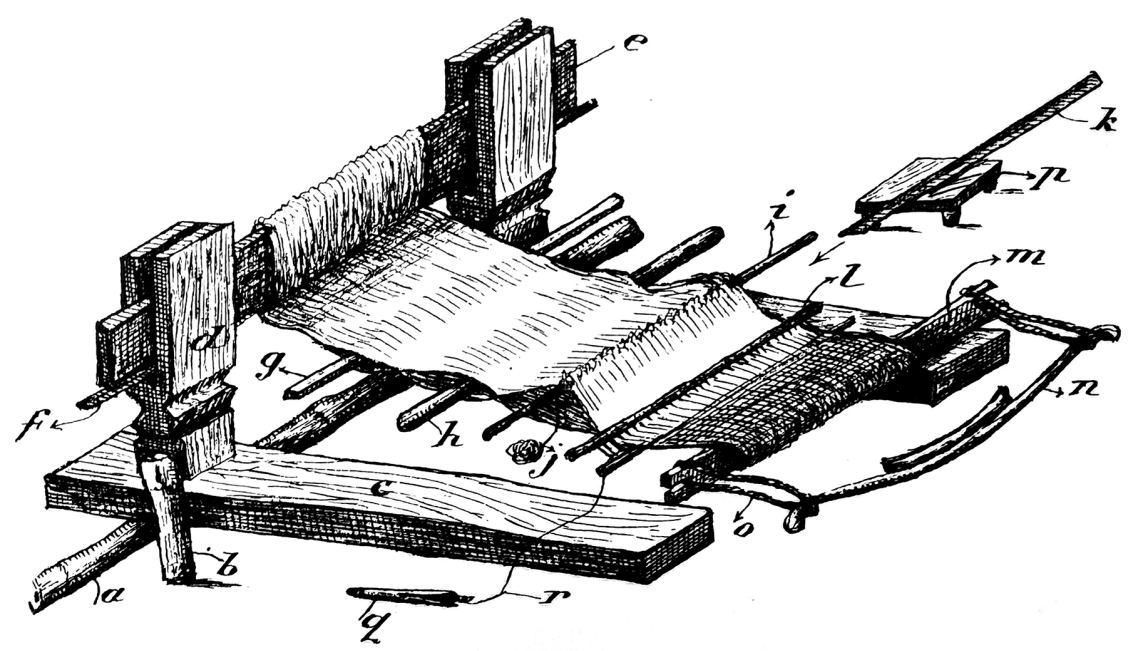

Fig. 2 - Weaving Tool from the Sundanese region (Jasper \& Pirngadie, 1912:122). a. Andir, b. Pancuh, c. Unjar, umpak or dadampar, d. Cakcak or gedogan, e. Panggulung or totogan, f. Galégér, g. Titihan, h. Limbuhan, i/j. Jingjingan, k. Baréra, l. Suri, m. Hapit, n. Caor, o. Tali caor, p. Rorogan, q. Taropong, r. Palét

weaver's foot does not press directly on the edge of the loom (see fig. 2). The second feature relates to the tie-dye process; weft-based ikat is used as a logical consequence of the use of the flat-warp type of loom. ${ }^{3}$

Following Wisseman Christie (1993), who used textual materials from Java, primarily inscriptions, this article will explain the types, functions, production techniques and symbolic aspects of the weaving process during the pre-Islamic period, as it is reflected in textual sources in Old Sundanese and in more recently-recorded pantun narratives. The sources that will be used are the following:

BM: Bujangga Manik (ca. 15th c.)

CP: Carita Parahyangan (prior to 1600)

DK: Demung Kalagan (Carita Pantun, recorded in 1970)

FCP: Fragmen Carita Parahyangan (prior to 1578)

KP: Kawih Pangeuyeukan (prior to 1700)

KSH: Kaputusan Sang Hyang (prior to 1600)

LK: Lutung Kasarung (Carita Pantun, recorded in Pleyte 1910)

PRR: Putra Rama dan Rawana (ca. 16th c.)

SA: Sri Ajnyana (ca. 16th c.)

3. While Buckley (2017) classifies weaving techniques into four types, Pelras (1972) classifies them into three. The technique used in Java (including the Sunda region) and areas with strong connections to India, are grouped into the "central" weaving culture. 
SD: Séwaka Darma (Kawih Panyaraman) (ca. 15th c.)

SSC: Sang Hyang Swawar Cinta (prior to 1500)

SSKK: Sang Hyang Siksa Kandang Karesian (oldest ms. dated to 1518)

SSMG: Sang Hyang Sasana Mahaguru (prior to 1500)

RT: Radén Tegal (Carita Pantun, recorded in Meijer 1891)

It should be noted that it is difficult to determine whether the terms for textiles and weaving in Old-Sundanese texts and carita pantun reflect the reality of their time. Ethnological evidence in the early twentieth century proves that most of the 16th-century terminology for textile and fabric motifs was still used, although some terms are not historically attested. In several examples, such as in the formulaic expression in the carita pantun, the author implicitly wants to associate his knowledge of the international world, such as mentioning imported embroidered fabrics from Baluk, Chinese silk, and looms with the highest quality materials from outside the Sunda region. These formulas clearly reflect the author's imagination rather than reality.

\section{Types of Textile}

The Sundanese-speaking area took part in international trading networks since the pre-colonial period, just as did many other areas in the archipelago. The earliest sources, whether local or European, help to give us a picture of the commercial activities and the commodities, especially textiles.

According to Tomé Pires' report in his Suma Oriental of the early 16th century, people from the kingdom of Sunda (regño de çumda) imported large amounts of coarse cloth ${ }^{4}$ from as far away as Melaka. They conducted active trade with Sakampung ${ }^{5}$ (which possessed abundant cloth), Tulang Bawang (present-day Lampung in southeast Sumatra), and Siam. Reportedly, Sundanese people also imported a variety of clothes, including from Keling and Cambay (Cortesão 1944: 169).

They buy white sinabaffs, both large and small, synhavas, pachauelezes, balachos, atobalachos (these are white cloths). They buy Kling cloths, enrolados of large and small ladrilho which are then marketable, and they buy much. They buy pachak, catechu and seeds from Cambay. They buy bretangis and clothes from Cambay, turias, tiricandies, caydes in quantities. A great deal is used there and bought for gold. Areca, rosewater and things like that are bought in Sunda.

4. The term "cloth" in this article refers in a general sense to any materials that are intended to be worn and that are produced through weaving, knitting, embroidering, or beating (tree bark).

5. As identified by Noorduyn \& Teeuw (1999: 217), Sakampung refers to what is now known as Tanjung Sakampung, on the eastern coast of the southernmost tip of Sumatra. In the 16th century it had close contact with Sundanese coastal districts and was economically important (Meilink-Roelofsz 1962: 92). 
The terms for types of cloth recorded by Tomé Pires are difficult to translate. Several among them have been identified by Cortesão. Balachos and atobalachos are a kind of thin cloth. White cloth is called enrolados, while bretangis is a kind of cotton garment (coloured blue, black or red) that was once exported from Cambay. Jean Mocquet, the French explorer, also explained in his record of his travels to Mozambique in 1670 that bretangis is a sheet of cotton cloth coloured blue and dark purple. ${ }^{6}$ I have been able to understand none of the other terms mentioned by Pires.

Now we shift to local sources. Inscriptions in the Old-Sundanese language from West Java have not provided much information about textiles from the Sundanese region, with the exception of the handful of Kebantenan inscriptions that are estimated to date from the 16th century. The Kebantenan inscriptions report that one of the objects given as an offering to the kingdom of Sunda in Pakuan was kapas timbang, which may well have been used as apparel. ${ }^{7}$ As attested in the Fragmen Carita Parahyangan, the tax burden imposed on those who were obliged to pay was approximately ten (sapuluh) carangka. ${ }^{8}$

Only through Old-Sundanese texts and Sundanese oral traditions do we obtain more information about textiles that were produced in Sundanese region in premodern times. Through the Fragmen Carita Parahyangan, we get the impression that autonomous Sundanese authorities in the territories of Galunggung, Denuh, Sang Hyang Talaga Warna, and other areas, offered a kind of tribute to the capital at Pakuan. Besides rice (pindo), ${ }^{9}$ buffalo (munding), essential oil (minyak haneut) and poultry (hayam), various kinds of cloth were also included among the offered goods (FCP 6a-7b). These cloths included non-coloured (white) and coloured cloth, with a standard unit of weight. There were two kinds of cloth given in offering, namely beubeur (ikat-woven cloth) and boéh (cloth in general) with a variety of colours: white (putih), red (beureum), black (wulung), multicoloured (boéh warna), as well as teak-blossom white (jati kembang).

6. Original quote: "sont certaines toiles de coton teintes en bleu et violet obscure" (1830: 211).

7. The passage in question: ${ }^{\circ}$ aya ma nu ṅabayu ${ }^{\circ} a n \cdot{ }^{\circ}$ iña ${ }^{\circ}$ ulah dek $\dot{n}$ nahəryanan. 'iña, ku na dasa, calagara, kapas timbam, pare dom dam pun. "If there is someone providing them livelihood, don't be eager to overburden them with the dasa, calagara, kapas timbang, paré dongdang" (plate I, side B, line 2-4) (Aditia Gunawan \& Arlo Griffiths, forthcoming).

8. Carangka is 'a basket of course bamboo plaits' (Hardjadibrata, 2003:153, sic for 'coarse'). The passage in question: ti kandangwesi pamwat siya ka pakwa[n], pedes telu barut, kapas sapuluh carangka, uyah salawé kelék, hayam salawé, "From Kandangwesi, their gift items to Pakwan: three barut of peppers, ten carangka of cottons, twenty-five kélék of salt, twenty-five chickens" (FCP.7a).

9. This word probably originates from Skt. pinda 'a ball of rice or flour offered to the pitṛs or deceased ancestors, a śrāddha oblation' (Monier Williams 1899: 625). 
Besides cloth in the form of untailored sheets, we find mention of three kinds of garment that were offered to the king, namely tipulung "head cloth," lilitan "shoulder cloth," and pélah "plaited waist-tie." The units of measurement for these kinds of textile were diverse: the unit for cloth (boéh) was kayu ${ }^{10}$ while for shoulder cloth (lilitan) it was teukteuk, ${ }^{11}$ and for head cloth (tipulung) it was batekan.

Terms that refer to types of cloth, both tailored and untailored, are plentiful in Old- Sundanese texts. The most important items mentioned by the authors are: tapih, lungsir, kasang, boéh, sutra, aben, poléng, dodot, simbut, cawet, and daluwang. In the following, I will attempt to define them one at a time.

Tapih is a lower-body garment, apparently not exclusively worn by women but also by men. Its shape may be similar to the present-day sinjang. ${ }^{12}$ There are two kinds of tapih: tapih béét, which literally means "small cloth," used as underwear that has to be tied with a kind of belt called bentén, and tapih luar, which was worn outside the tapih béét. The tapih luar is described as fluttering, and as having the length of an adult's shin (KP.57-58). Pieces of tapih cloth were also used to tie or to wrap sirih pinang (betel nut) (BM.363). It seem that tapih is a type of cloth with small size. The giringsing wayang motif, the only kind of double-ikat (warp and weft) that has been produced in Bali up to the present day, was used for tapih (SA.686 \& SD.47.9).

The editors of Old-Sundanese texts translate lungsir as satin or silk cloth (for example Noorduyn \& Teeuw, 2006 on BM.351). This presumption may be due to its relationship with the same word in Old Javanese, which is often juxtaposed with the word sütra. ${ }^{13}$ This cloth could be used as a curtain (kulambu) (BM.189) or a shawl (karémbong) (SD.47.10). The unit of lungsir is kayu. The word lungsir is not found in Modern Sundanese.

Boéh generally refers to sheets of cotton cloth (FCP.6b-7a). It is used to bandage or to wrap; as in the case of the casket containing Dewi Sita when she was submerged into the river by Laksamana (PRR.253). Boéh was included among the offerings of vassal kings to the paramount king. The units used were lawé (literally meaning 'yarn') and kayu. The boéh calincing motif (Averrhoa

10. Probably kayu is parallel with Modern Sundanese kayuh, 1 kayuh $=5$ nyéré, 1 nyéré $=10$ sheets of laway (skein of cotton). As an illustration, the FCP records that seven kayu of cloth could cover an elephant's hide. Malay kayuh has a similar meaning: "roll (of fabric or cotton)" (Kamus Dewan: s.v. kayuh).

11. In Old Sundanese, the word teukteuk means "cut, break." Cf. for example, the sentence in PRR.1483: diperang buru-binuru, silih teukteuk silih kedék "in combat, pursuing each other, breaking each other and slashing each other."

12. Cf. Old Javanese tapih: "garment worn by women around the lower part of the body" (Zoetmulder 1982: s.v. tapih).

13. For example in Rāmāyaña 8.90: dodotnyālit sūtra len lunisir abhrā "and their outer garments were of fine silk or of shining lunsir cloth" (Kern 2015: 172; Robson 2015: 207). 
bilimbi) and a type of boéh limur are also mentioned (BM.212, 392). It is interesting to note that limar is recorded in Modern Sundanese dictionaries as a "kind of floral silk material; waistband made of this material"(Hardjadibrata, 2003: 498), but in Old Javanese, limar is an older form than limur, which latter is only recorded in the Kidun Harșavijaya. Both refer to kinds of silk cloth (Zoetmulder 1982: s.v. limur).

Kasang is a broad cloth that often refers to curtains and forms part of a house, especially hanging down in doorways (BM.184, 187, 188). On the bottom it is decorated with gems that jingle when someone parts them. One of their primary components is boéh larang (SD.44). The type of kasang imported from outside Sunda originated from Pahang around the 15th century (BM.190). There could be a variety of kasang motifs, including motifs based on narrative stories (cacaritaan).

Sutra is a kind of high-quality cloth mentioned in the context of imported textile: in its occurrences in Old-Sundanese texts, this word is always juxtaposed with Keling (BM.1740, 1747) or with Chinese shoulder cloths (sasampay sutera Cina, BM.253).

Aben refers to cloths called "kemban" in Indonesian that are worn by women to cover the upper body (KP.55, SA.687). In Kawih Pangeuyeukan, Raden Jaya Keling advises his wife, Sakéan Kilat Bancana, to cover her breasts with this kind of cloth and never to allow them to be seen (KP.55). Pwah Aci Kuning, a beautiful nymph, is wearing an aben with the gula manikem ("sugar jewel") motif (SA.687).

Poléng is mentioned by Bujangga Manik who wore this cloth on his journey to the east (sakaén poléng puranténg, BM.251). Noorduyn \& Teeuw (2006) did not find the word puranténg as a textile motif elsewhere, but the anonymous autors of the Séwaka Darma mentions a motif of naga puranténg (crossing snake?). In Old-Javanese textual sources, this cloth has a black and white, but also multicoloured patterns (Zoetmulder 1982: s.v. polen்).

The meaning of dodot in Old Sundanese is not very clear. When it appears, this word always refers to stately attire that is fit to be worn by the king (SSMG.37, SA.262).

Kampuh is decorated with golden thread (SA.816). It is not clear what the function of this cloth is, but it may well be similar to the Old Javanese kind, ${ }^{14}$ which is used as a lower-body garment. However, in Sundanese texts there are indications that kampuh was also used for curtains.

Simbut or salimbut means blanket in Modern Sundanese, but it appears that this blanket was not only used for sleeping, but also as attire for travelling, as in the case of Bujangga Manik. The simbut used by Sang Ameng Layaran was an embroidered cloth from Baluk (BM.252). In Old-Sundanese texts, the word

14. Zoetmulder (1982: s.v. kampuh) translates it as a "garment worn around the lower part of the body" in the context of Old Javanese. 
simbut is usually juxtaposed with cawet. This latter word refers to a kind of lower garment or loincloth. Jákl (2016) has discussed the meaning of cavat in Old-Javanese sources, where it exclusively refers to a loincloth.

Finally, the mention of daluwang in the context of clothing indicates that the Sundanese also knew traditions of clothing manufacture from bark (SSC.697-698).

\section{Function}

For Sundanese people of the 15th and 16th centuries, at least according to the Siksa Kandang Karesian, cloth was a primary necessity, just like food, weapons and domesticated animals. If just one of these is not fulfilled, a person is considered as one who weakens the instructions (durbala siksa). ${ }^{15}$

In the thought-world of pre-Islamic Sunda, wearing clothes is a reflection of a human's higher consciousness (upageuing). Upageuing is a hybrid Sanskrit and Sundanese word, and the central element of the trigeuing "three consciousnesses," which consist of geuing (consciousness), upageuing (higher consciousness), and parigeuing (ultimate consciousness) possessed by humans. Geuing is the lowest consciousness, that is, the consciousness of consuming food and drink. Upageuing is higher, as it distinguishes humans from animals, making the former aware of the need to cover their genitals by wearing clothes. Finally, parigeuing is the ultimate consciousness that allows humans to control others through speech that is civilized and poetic (SSKK.14). ${ }^{16}$

In the Sang Hyang Sasana Mahaguru (\$39), three elements that constitute cloth are associated with the three main components of life: the body (sarira) is associated with the basic material of the wari flower (Tabernaemontana divaricata), intellect (hdap) is associated with thread (kantéh), and correct judgement (sang hyang pramana) is associated with cloth (bwaéh = boéh), see the following quotation:

15. SSKK.14-15: cocooan ulah tihap meuli mulah tihap nukeur, pakarang ulah tihap nginjeum, simbut cawet mulah kasaratan, hakan inum ulah kakurangan, anak éwé pituturan sugan dipajar durbala siksa, "When owning domestic animals, do not swap them as soon as they are bought. Do not always exchange tools. Do not run out of blankets and clothers. Do not be deficient in food and drink. Remind your children and wife that one doesn't want to be known [as someone who] weakens the intructions (durbala siksa)."

16. SSKK.14: geuing ma bisa ngicap bisa ngicup di na kasukaan, ya geuing ngaranna; upageuing ma ngaranna bisa nyandang bisa nganggo, bisa babasahan, bisa dibusana, ya upageuing ngaranna; parigeuing ma ngaranna bisa nitah bisa miwarang ja sabda arum wawangi, nya mana hanteu surah nu dipiwarang ja katuju nu beunang milabuh siloka, "The consciousness allows one to taste and drink in pleasure; that is called consciousness. What is called the higher consciousness is that allows one to carry, use, speak, wear clothes; that is called higher consciousness. What is called the ultimate consciousness, is that allows one to order, command, because his speech is fragrant, such that the one who is commanded does not feel insulted, because his heart is touched by someone who is able to compose verse." 
nu kangken wungawari ma sarira; nu kangken kanteh ta ma, na hdap; nu kangken bwaéh, sang hyang pramana.

What is called wari flower is the body; what is called thread is the intellect; what is called cloth is correct judgement.

Clothing reflects the normative standards of any society. People in the premodern Sunda region believed that a woman ought to cover her breasts with an aben (KP.55), and that, when meeting a superior on the road, one ought to wear full attire (cangcut pangadwa) (SSMG.2, SSKK.8). ${ }^{17}$

Woven cloth was also used as a gift to propose marriage. Besides carrying "betel as a symbol of proposal" (seupaheun pananya tineung), Jompong Larang, who represented the parent of the prospective bride, Sakéan Kilat Bancana, offered other objects (pikaéneun) when he proposed to Bujangga Manik in the name of the princess (BM.503-506). Besides these objects, the proposer also added high-quality anten and limur cloth, as well as shouldercloths with wayang motifs (sabuk wayang), with the aim of convincing the prince of the love of Sakean Kilat Bancana (BM.513-514).

Cloth could also be used as a reward to someone considered to have given a service. Bujangga Manik gave a sheet of cloth to the captain who had transported him safely to Bali. It is very likely that the cloth given by Bujangga Manik was not merely a souvenir, but a form of payment that was current at the time, which was considered to have monetary value.

\author{
'akiing juru puhawang, \\ éboh midua rahayu, \\ éboh ta urang papasah, \\ dahini kaén aing, \\ ini pangidian aing.'
}

\author{
[Bujangga Manik:] 'My Lord Captain \\ and again we two are safe \\ and we two will part again \\ this is my cloth \\ this is my gift.'
}

Clothing items, especially salimbut and cawet, were also goods that were offered by residents when government officials came to visit them, as a sign of their loyalty. ${ }^{18}$ Because of their special properties, items of woven cloth, just

17. The meaning of pangadwa, both in Old Sundanese and Old Javanese, is problematic. Zoetmulder (1982, s.v. panadwa) wonders whether the basic meaning is adu or $d w a$. I would be inclined towards the latter option, particularly since it is always mentioned with cangcut "trousers," so that pangadwa would point to the "upper garment" as what comes second after trousers.

18. SSKK.9: nihan muwah, jaga rang kadatangan ku samé pangurang dasa, calagara, upeti panggeres reuma maka suka geuing urang, maka rasa kadatangan ku kula kadang, ku baraya, ku adi lanceuk anak mitra suan kaponakan, sakitu éta kangken, ngan lamun aya panghaat urang, kicap inum simbut cawet suka drebya, "The same applies also when we are visited by all types of pangurang, dasa, calagara, upeti panggeres reuma, 
like domesticated animals, were family heirlooms that were passed down the generations. ${ }^{19}$

In the data presented above, we find indications that cloth was a symbolic object that was used for marriage proposals and was given in inheritance; that it expressed the normative system current in society, and that it functioned as a tool for socialisation, as well as an object of trade between Sundanese people and the outside world.

\section{Weaving}

At least since the beginning of 16th century, as described in the Sang Hyang Siksa Kandang Karesian (whose oldest manuscript dates to 1518), we find mention of two kinds of cloth production. There are two terms that are distinguished in connection with the decorations applied on cloth. The first is the term tulis, which was translated by Holle (1867) as "batik" (waxresist dyeing). This translation of tulis as "batik" is controversial. Wisseman Christie (1993:190-192), in her discussion of the term tulis in Java, finds that there are three senses of tulis that seem not necessarily to refer to what we know as batik today. The three are tulis warna (a coloured style of cloth decoration), tulis wətər (abdominal cloth decoration?), ${ }^{20}$ and tulis mas (a goldcoloured style of cloth decoration). These three techniques may not have used colour-resistant materials such as wax, nor used the canting (pen-like tool used to apply liquid hot wax in the batik-making process), but may on the contrary have been drawn directly on the cloth, as happened in Bali during the premodern period. ${ }^{21}$

then our hearts feel cheerful, feeling like being visited by family, relatives, siblings and brothers, children, friends, suan and nieces. That is the parable. But if we have compassion of ours, [give them] food, drinks, blankets, clothes, and our wealth."

19. SSKK.19: ladang pepelakan wenang dipikakolotan, ngaranna manik bijil ti pretiwi, ladang heuyeuk, ladang cocooan wenang dipikakolotan, ngaranna mirah tiba ti akasa, "The fruits of agriculture can be made into an heirloom. These are called jewels that come from the earth. The fruits of domestication and livestock can be made into an heirloom. These are called rubies that fall from the sky."

20. I suppose that there is a link between watər in Old Javanese and beuteung in Old Sundanese. In Old Sundanese, this word does not always mean "stomach," but also "stop (doing something), to cause to stop" (Hardjadibrata 2003: s.v. beuteung). This does not exclude the possibility that the word watan refers to the wax-resist dyeing technique that is typical of batik today.

21. This fact is attested for example in Vainban Videya (Canto 1.87a, 3.64a, 3.117a), a middle Javanese text from Bali, written in Gelgel in the second half of 16th century (Robson 1971). 
The second term mentioned in SSKK is boéh "cloth," which was specifically produced by a weaving process. ${ }^{22}$ The production of both tulis and boéh was done by a professional or at least semi-professional, namely a decorator (lukis) ${ }^{23}$ and a weaver (pangeuyeuk). It seems that a few other types can be added, such as embroidery (susulaman, KP.83) which, based on the texts, is limited to blankets imported from Baluk (Baloochistan?). A type of cloth called songkét is also mentioned, even though there are no satisfactory explanations about the technique used to make it. ${ }^{24}$

What drew my particular attention in the study of the Old-Sundanese texts was the weaving tradition. The instrument for weaving is called heuyeuk. The verbal derived from heuyeuk is ngeuyeuk (to weave). As mentioned above, the weaver is called pangeuyeuk. The mention of the term pangeuyeuk among terms designating professions indicates that weaving was done by professionals, or at least semi-professionals.

In contrast to the case of India and a few other regions in the Nusantaran archipelago, where men participated in weaving activities, in Sunda, weaving was an exclusively female affair. This fact is reflected in almost all the ancient textual sources from this region. Women weaved in special pavilions or on the porches of their homes. These special pavilions are called Balé Pangeuyeukan (SSC.1125), or Balé Keusik Paninunan (LK, passim). Other terms include Balé Tulis (LK, passim), which perhaps refers not to the place for weaving with the ikat technique, but rather to the place for making batik. The texts do not make it clear in what relation the Balé Pangeuyeukan stood to the residential quarters, but Pleyte (1912: 14, pl. 2) illustrated a pavilion in the beginning of the 20th century, namely a pavilion called a ranggon pangeuyeukan, which was separate from the house, with a height equal to three fully-grown adults.

The ideal image of a woman was associated with her skill in weaving cloth. The author of the Sang Hyang Swawar Cinta, through the offering of an initial invocation (rajah) at the beginning of his narrative, hopes that the incense smoke that he has offered to the deity, if it encounters a young woman (bwacah opoy), might cause that woman to become beautiful and to assume the attributes of female excellence. Among these ideal characteristics,

22. In dictionaries of Modern Sundanese, boéh is defined as a white-coloured cloth. In Old-Sundanese texts such as the Sang Hyang Siksa Kandang Karesian and Kawih Pangeuyeukan, this word seems not only to refer to white cloth, but to cloth whose raw material is kapas "cotton."

23. The meaning of tulis is the activity of "painting or decorating" cloth. This sense is more or less the same as the term tulis that is found in classical Malay texts, where it also means to decorate a medium. See Gallop (2013) in connection with this topic.

24. It is probable that this term is the same as Indonesian term songket, referring to weaving by hand using gold colored threads. The Old-Sundanese metaphor nywangkét poék-poék (SSC.156, see below) gives an indication that the gold threads will glow and sparkle in the dark. 
skillfulness in weaving is very important. The most excellent woman is one who is able to weave cloth in the night time (bisa meubeur malem-malem) and is able "to embroider [cloth] with gold threads" in pitch darkness (nywangkét pwaék-pwaék). This imagery can be seen in the verses below:

mangka nguni lamunna
ninggang ka bwacah opoy
mangkana galemuh tulus
galepong bongsor
geulis pawilis
doéh éndah pada wala
demuk pipi timbun buuk
doéh panjang kwanéng
caropwang puhu buluna
hapitan karawaléa,
ceta nywangkét pwaék-pwaék,

ceta neuleum malem-malem,
It is also thus if, (incense smoke) strikes a young woman, it makes her shapely and healthy, strong of body, beautiful, voluptuous, all youthful in appearance, chubby-cheeked, with thick hair, plump, tall, creamy-skinned, smooth without body-hair.

She is strong enough to carry the hapit, Skilled at embroidering with gold threads in the dark, Skilled at dyeing in the night time, Skilled at twining in the day time.

SSC. $147-158$

The idiom applied to women who have achieved this degree of excellence is hapitan karawaléa (SSC.155, BM.537-41, KP.408), which is associated with a weaving tool. Hapitan is related to hapit, which is one of the tools that rest on the weaver's lap. Noorduyn \& Teeuw (2006) connect karawaléa to the Old Javanese word karawalya "invulnerable" (from Sanskrit kāravella, kāravalli) (Zoetmulder, s.v. karawalya). ${ }^{25}$ My guess is that this expression is an idiom for a woman whose legs are "strong and unfatigued" while bearing a hapit. If so, this idiom points to the readiness of a woman to carry a hapit. However, this does not preclude the possibility that this expression contains an allusion to female sexuality; namely, a woman who is sexually mature enough to marry, as in the verses below.

\begin{abstract}
sugan sia hamo nyaho, tohaan geulis warangan, rampés rua rampés tuah, teher geulis undahagi, hapitan karawaléa.
\end{abstract}

Probably you do not know, a beautiful woman ought to be wed, of lovely form and good behaviour, also pretty and skilful, who can bear the hapitan.

BM.537-541

25. Zoetmulder arrives at the meaning "invulnerable" for karawalya by relating this word with timbul, which means both "a bread-fruit" and "invulnerable." The word kāravella or kāravalli in Sanskrit means "gourd." (Monier Williams 1899: 275). 
Further on in the same text is found a formulaic description about weaving, which is narrated by Bujangga Manik when seeing his mother weaving on the porch of their house (BM.156-164, see below). It is important to specifying interpretation of this expression in order to refine our understanding of the cultural importance of weaving in premodern Sunda.

ambuing kasondong ngeuyeuk, My mother can be seen weaving, buat nu di tepas bumi, eukeur ngeuyeuk eukeur working on the porch of the house, weaving and tying, meubeur, eukeur nyulanggé mihané, netting and rolling the thread on pihané,

neuleum nuar nyangkuduan, dyeing the cloth black, yellow, and red, ngarancé ${ }^{26}$ kantéh pamulu, pressing the woven threads, ngela sepang ngangeun hayam. boiling the sappan ${ }^{27}$ and the hayam ${ }^{28}$ wood.

What is very interesting is the appearance of the word meubeur, which literally means "to tie." This word is recorded in the dictionary of Hardjadibrata (2003) - which takes its material from the Sundanese-Dutch dictionary of Eringa (1984) - as follows:

meubeur, the warp yarns of a fabric wrapped around in places (so that during dyeing those places do not take any dye: the so-called ikat or tie-dye process, applied on kasang fabric); ngabeubeuran, ngabeulitanan put a waistband on so.; ngabeubeurkeun/meubeurkeun, ngabeulitankeun use st. as a waistband, wrap (a cloth) around the waist; dibeubeur, dibeulitan wear a waistband or belt, have a waistband/belt on.

26. In the edition by Noorduyn \& Teeuw (2006), we read in line 161 nyulagé and in line 163 ngaracét. I emend the text because the words nyulanggé and ngarancét are recorded in modern Sundanese dictionaries. Non spelling of homorganic nasals is very common in Old-Sundanese manuscripts.

27. Cf. Old Javanese sapan' the sappan-tree (Caesalpinia sappan). Wilk.: "a low thorny tree with yellow flowers; the wood is cut to pieces and boiled to produce a red dye." (Zoetmulder 1982: s.v. sapan்).

28. The translation proposed by Noorduyn \& Teeuw (2006) for ngela sepang ngangeun hayam, "cooking with sappan and making chicken and vegetables," is somewhat problematic. Zoetmulder (1982, s.v. hayam) notes kayu hayam-hayaman as "a part. kind of tree?". Unfortunately, this species of tree has not been determined with certainty. From the context, the whole expression seems to refer to the processing of this kind of tree to produce a dye. 
The appearance of meubeur indicates that weaving techniques using tied threads that were not dyed, that is ikat-weaving (tie-dye process), were already practised in Sunda as early as the 15th century.

\section{Colour}

The question to which I would now like to turn concerns the perception of colour in ancient Sundanese society. Through the verses above that depict weaving, we learn about the basic perception of colour via the practice of dyeing cloth. This perception seems to have been influenced by pre-Islamic cosmological concepts. Old-Sundanese texts containing poetic formulas about dyeing can give us a picture of the basic clasification of colour that was current in Sundanese society. The expression neuleum nuwar nyangkuduan (line 162), which Bujangga Manik's mother performed, contains three verbs that point to dyeing activities.

The word neuleum, as noted in the dictionary of Danadibrata (2006, s.v. teuleum), means "dyeing cloth in mud, resulting in a black colour." This is a technical term, because in general neuleum itself means "to submerge so, to dye," deriving from the word teuleum "drown."

The word nuwar is perhaps related to the word cituar which is only recorded in Danadibrata's dictionary (2006:144). Danadibrata notes that cituar is "dyeing water of a yellow colour to dye white thread." ${ }^{29}$ Noorduyn \& Teeuw (2006) also define nuwar as a yellow dye. The base word is not found in the dictionaries, but it is very likely $u w a r$, if we compare it with the Old Javanese word $u b a r$, and keep in mind that the interchanging of $b$ and $w$ is a common phonological phenomenon in the Old Sundanese and Old Javanese languages. Zoetmulder (1982, s.v. ubar) added an asterisk to the lemma, meaning that the base word is not found standing on its own in any text. Nevertheless, the active form anubar is attested in the meaning "to make red(-hot), make glow; to dye red." Wisseman Christie (1993:207) also notes that in Javanese of the middle period, beside indigo and Indian mulberry, other dye ingredients were also mentioned, such as sappan wood, lac, and "ubar wood" (Euginia sp., Linn.). Outside Java, for example in the Doyo weaving traditions of the Dayak, uwar wood is also used to produce a light brown colour. From the contextual examples provided by Zoetmulder, which are always associated with fire, as well as the Dayak tradition of producing light brown pigment, I tend to believe that $u b a r$ more likely produces a yellow colour, perhaps with a shade of brown, instead of red.

The colour most commonly mentioned is red, which was produced through the process of nyangkuduan. This is the active form of cangkudu (Indonesian mengkudu, Old Javanese wunkudu, Morinda citrifolia, Linn.), namely to

29. "cicelep nu warnana konéng pikeun nyelep kantéh bodas." (Danadibrata 2006:144). 
dye something with Indian mulberry to produce the colour red. This basic ingredient was very commonly used in ancient Java. Goris (1954: II) notes that dyeing with Indian mulberry had already begun in Bali since the 9th century. The colour red was also produced from lac wood and sappan wood (Modern Sundanese secang); in Sundanese weaving traditions in the early 20th century, gandola beureum (Badela rubru L) was also noted by Pleyte (1912) as a red dye ingredient.

From the preceding passage from Bujangga Manik's versified travelogue, we may infer that the colours normally used to dye cloth were black, yellow and red. To these three colours we must add one basic colour, which is none other than the underlying colour of the cloth before it is dyed, namely white. These four basic colours are linked to the context of the Saiva religious cosmology as it was prevalent in ancient times on the islands of Bali and Java, including pre-Islamic Sundanese society as reflected in Old-Sundanese texts.

This basic colour classification is systematically linked to the cosmology of the cardinal directions. In the Sang Hyang Siksa Kandang Karesian (III-IV), space is divided into the four cardinal directions plus one (centre), comprising the unity of space in "all directions" (desa kabéh):

desa kabeh ngaranya, purba, daksina, pasima, utara, madya; purba timur, kahanan hyang isora, putih rupanya; daksina kidul, kahanan hyang brahma, mirah rupanya; pasima kulon kahanan hyang mahadéwa, kuning rupanya; utara lor, kahanan hyang wisnu, hireng rupanya; madya tengah, kahanan hyang siwah, aneka warna rupanya; nya mana sakitu sang hyang wuku lima di na bwana.

All the directions are: purba, daksina, pasima, uttara, madya. Purba is the east, the abode of the god Iswara, whose colour is white. Daksina is the south, the abode of the god Brahma, whose colour is red. Pasima is the west, the abode of the god Mahadewa, whose colour is yellow. Utara is the north, the abode of the god Wisnu, whose colour is black. Madya is the centre, the abode of the god Siwa, whose colour is multicoloured. That is what is called the five sacred divisions (sang hyang wuku lima) of the universe.

We see here how four colours are associated with the four cardinal directions: white with the east, red with the south, yellow with the west, and black with the north. The centre is multicoloured. Similar associations are found in the Sang Hyang Swawar Cinta, when the author mentions incense smoke floating in the five directions, as well as in the mantra text Jampé Panglokatan. The colour symbolism involving the cardinal directions along with deities in each are fundamental concepts in the cosmological system that was prevalent in preIslamic Java, and is still valid today both in Java and Bali (Damais 1969).

In the context of Sundanese textile production, Djajasoebrata (1988) mentions that these four primary colours have symbolic meanings. Black and yellow would be profane colours, while red and white would be sacred. I have not been able to determine how Djajasoebrata came to this interpretation, but it appears that such a hypothesis is in accordance with data from Old-Sundanese 
texts, especially the Warugan Lemah (Aditia Gunawan, 2010). In relating the colours with four cardinal directions, it seems plausible to consider purwa and daksina (east and south), or front and right, or white and red, as the sacred areas, while pasima and utara (west and north), or back and left, yellow and black, occupy the profane areas. ${ }^{30}$

There is sufficient reason for us to suppose that the beliefs of the Baduy people reflect the same kind of cosmology. From ethnographic reports (Judistira K. Garna 1987 and Cecep Eka Permana 2006), we learn that they hold east and south to be the sacred directions. Every visiting guest must enter from the north or the west. The graves of ancestors, sanctified statues, forbidden forests, and inner Baduy (Baduy Dalam) settlements are located in the southernmost area of Baduy settlement. The belief in the separation of sacred and profane in these areas also applies to colours, as shown in the attire of Baduy people. The colour of the attire of the "outer Baduy" and the 'inner Baduy' display two extreme poles: white is used by the "inner Baduy" and black is used by the "outer Baduy." It should be added that Danadibrata (2006) mentions that in the Baduy language, red is called siang, and that this is a taboo word for the people in question.

Beside the four primary colours, there are also other colours mentioned, but these occupy a secondary position. The active form ngasumba refers to the activity of dyeing cloth with kasumba (Chartamus tinctorius) which seems to produce a saffron red or a pink colour (SSC.161). The colour orange, the colour gadung (green?) (SSC.160), pada lungsir, as well as blue thread (kantéh biru) are also mentioned (KP.363).

\section{Decorative Patterns}

Skill, combined with knowledge of colours, are combined to create motifs in textile production. The information below concerning motifs and categories is based on Mamat Sasmita's interpretation of various textile motifs mentioned in the Sang Hyang Siksa Kandang Karesian (1518), based on manuscript L 630 in the National Library of Indonesia, in a long and useful article published in the magazine Manglé (February-March 2015). My own interpretation differs from Mamat Sasmita's only to a small extent. I add some variant readings from another manuscript of Sang Hyang Siksa Kandang Karesian (L 624 in the National Library of Indonesia), and in some relevant cases, try to compare them with OldJavanese sources. I add also some terms relating to the motifs that I found in other

30. The assumption that the east and south are considered sacred is still found in the Sundanese proverb ulah lali ka purwa daksina "do not forget the beginning and the end" (lit.: do not forget about east and south," cf. Danadibrata 2006: 552; Hardjadibrata 2003: 251), which is intended as advice for the Sundanese so as not to forget their origins. The fact that purwa originaly meant east and daksina south is actually unknown to contemporary speakers of Sundanese. 
Old-Sundanese texts. Since Mamat Sasmita published his article in Sundanese, it seems useful to represent his interpretation here, along with mine.

\section{Decorated Textile Motifs}

In the Siksa Kandang Karesian are recorded nine tulis (decorated cloth) motifs and 25 decorative patterns on boéh (woven cloth).

1. Pupunjengan (mss.: pupuñjənan). Mamat Sasmita interprets this based on the possibility of transformation of the sound $\tilde{n}$ to $y$ in Sundanese: puñjeng > puyeng 'circling' and relates it to the modern Javanese word $u \tilde{n} \partial \dot{n}-u \tilde{n} \partial \dot{n}$ ' hair whorl'. Zoetmulder (1982) affixed the asterisk sign to the entry puñjon in his dictionary, but seen from the context, the phrase romāpuñjan abutak which he quotes, the translation "spiraling hair with a bald section" (RL 11.165) makes sense. Mamat Sasmita also convincingly connects the shape of this decorative pattern with the cloth motif bubujalan "like a spiral" in the modern Sundanese weaving tradition recorded in Soegeng Toekio (1987).

2. Hihinggulan (ms. L 624: higul-higulan). Mamat Sasmita, paying close attention to Noorduyn \& Teeuw's (2006) edition of three OldSundanese poems, seems to accurately relate the hihinggulan motif to the Old-Javanese word igul. The OJ verb anigul "writhing" is applied to fish. It seems that this motif resembled a writhing fish.

3. Kekembangan. This motif definitely refers to imitating the shape of flowers. What kind of flower is used as a model by the decorator (lukis) is difficult to determine.

4. Alas-alasan. Mamat Sasmita interprets this motif as one that "imitates the forest," by comparing it with similar motifs that still thrive in Bali. It should be added that in Bali in the 16th century, as reflected in the Malat, this word is also mentioned as a kind of ornament on a keris hilt. The Nawaruci, which was written in approximately the same period, mentions this pattern as a decorative ornament on a fish pond. ${ }^{31}$

5. Urang-urangan. It is clear that this refers to the shape of shrimp (urang).

6. Memetahan (mss: L 630 momotaḩhan, L 624 mimilaḥhan). Mamat Sasmita interprets this motif as the shape of an elephant's trunk, which is based on the word meta in the Sundanese idiom gajah meta "crazed, drunken elephant." The word meta comes from the Sanskrit matta, which also has the connotation of "being passionate (because of periodic state of large rise in reproductive hormon called 'musth'),"

31. Mal 7.43b: (kris) asosoca vaidurya trap-trap avarna alas-alasan; NR 37.13: araras kan tambak laleyan inukir binəbad ati pinan arenten lavan alas-alasan (Prijohoetomo 1934: 37). 
specifically in relation to elephants. Nevertheless, we find in classical Malay peta /pota/ that refers to "picture," and the verbal form dipeta "draw" is found: bagai gambar baharu dipeta, "like a picture newly drawn" (Gallop, 2013:17). In the practice of making a decorative cloth, maybe the decorator had an sample of the picture to be copied. I suppose that this is the most plausible interpretation. It should be added that manuscript 624 contains the reading mimilahan, which seems to derive from bilah, which can be understood in the same sense as belah "split in two" in Indonesian.

7. Sisirangan (ms. L 624: sasarainan). Mamat Sasmita interprets this motif as the sasirangan motif that has developed in Banjarmasin. In Old Javanese, siran is also recorded in other contexts, refering to a pattern with diagonal lines or diamond shapes. ${ }^{32}$

8. Taruk hata (ms. L 624: tataru-hataan). Mamat Sasmita interprets this motif as the leaf of a climbing fern (Lygodium circinnatum sw.) that is still recorded in dictionaries, the size of whose stem is as large as the stem of the coconut frond. Its stem is often used as a cord, such as to tie up baskets. Taruk itself means to cut something with the sharp tips of a flame tree, or to pick something by hand. This motif depicts the stem and leaves of the climbing fern.

9. Kembang taraté. This motif refers to the lotus flower (Nelumbo nucifera).

\section{Motif/Types of Woven Textile}

For the kinds of woven cloth, 25 motifs or types of boéh are recorded in the Sang Hyang Siksa Kandang Karesian, as follows:

1. Kembang Muncang (mss: mucan்). Muncang (Aleurites moluccana) is a kind of plant the size of the index finger, containing a very hard shell (Indonesian: kemiri). In Modern Sundanese, its flower is called rinduy, and it seems that this is what is meant.

2. Gagang Sénggang. Sénggang is the name of a plant that is still known in Modern Sundanese. Mamat Sasmita notes several kinds: sénggang bodas (Amaranthus hybridus), sénggang pucuk(Amaranthus spinosus), and sénggang monyét (Amaranthus blitum). He also mentions bayem or bayem leuweung, whose stems are thorny. It seems that this motif has the form of amaranth and its stem. I had the opportunity to see this batik motif, thanks to an owner of a gagang sénggang cloth in Kampung Adat Cigugur, Kuningan.

32. The contexts in Old Javanese are, among others, Mal. 8.101b: asalin kampuh ira pan்ulunin pik sinasar sisiranan asabuk devanga; Ww 1.99a: dodote bot Tuban cinirup siniran் in pingir; $4.11 \mathrm{a}$ : vastra pinadu randi mungv in təriah siniran் varna. 
3. Samélég. Mamat Sasmita does not give an interpretation of this decorative designs. I suggest that this word is a corruption of samé lék, bearing in mind that the aksara $k a$ and ga are often interchanged in manuscripts. If this conjecture is correct, this motif can be approximated as a motif that resembles (samé) the shape of the moon (lék). It cannot yet be determined whether a full or crescent moon is intended.

4. Seumat Sahurun. A seumat is a small object made of bamboo leaf or wood whose shape is like a toothpick, about 4 or $5 \mathrm{~cm}$ in length, whose function is to pierce food-wrappers made of banana leaf. Sahurun means a group. Based on this assumption, Sasmita interprets it as seumat placed in a row.

5. Anyam cayut. According to Mamat Sasmita, the word cayut means a cage made out of kiray leaves, coconut leaves, or palm leaves, which is often used as a basket. Jasper (1912b: 217) mentions various anyaman patterns from Ciawi Tasikmalaya which contain the word cayut: poléng cayut pinggir, poléng cayut item, poléng cayut beureum, poléng cayut tumoké, poléng cayut campaka, poléng cayut renyu, poléng cayut samangka, poléng cayut rakit putih. For this reason, Mamat Sasmita holds the view the cayut rather resembles the poleng pattern.

6. Sigeji. Mamat Sasmita does not interpret this decorative pattern, and neither do I. This word does not appear in the dictionaries.

7. Pasi-pasi. Mamat Sasmita does not interpret this pattern. Perhaps there is a connection with Old Javanese pasi, which derives from the Sanskrit paśi, pāsi "stone." Reduplication often denotes plural. If this is the author's intention, then pasi-pasi may resemble the shape of stones.

8. Kalangkang ayakan "ayakan shadow." Ayakan is a tool for catching fish or for sifting. If sunlight shines on it, a shadow appears that resembles poléng cloth. Such is Mamat Sasmita's interpretation. Nevertheless, I do not exclude the possibility of diagonal poléng shapes, bearing in mind that the shadow of ayakan is usually at a diagonal to the basic shape.

9. Poléng raganis. Mamat Sasmita bases his interpretation on the reading rengganis, while raganis is what is written in the manuscript. He argues that rengganis derives from rengga which means "decorated." If so, poléng rengganis would mean a poléng cloth that is decorated in a similar fashion. I offer the reading raganis, which seems to be related to the Old Javanese word rāga which means "red." Nis by itself means a negation. In this context, it may mean white. Apparently what is meant by poléng raganis is a composite form meaning "red and colourless (white)." I cannot exclude the possibility of interpreting raganis as raga+anis, which would mean "cooling red."

10. Jayanti (mss.: jayati). According to Mamat Sasmita, Jayanti (Sesbania sesban; Merr) is a small tree whose leaves resemble those of the white 
leadtree (Leucaena leucocephala). Sasmita interprets this to refer to the leaves, since the word kembang (flower) is not included in the name of the pattern.

11. Cecempaan (ms. L 624: cicinaan). Mamat Sasmita offers two possibilities for this decorative pattern. The first refers to the champak flower (Michelia champaca), for in Malay or Acehnese it is often referred to as the cempa flower. The second possibility refers to Campa, a region that is occasionally mentioned in Old-Sundanese texts. Looking at the variant that is found in L 624, namely cicinaan, it seems that the second possibility may have to be given preference.

12. Paparanakan. Mamat Sasmita does not interpret this decorative pattern. Its meaning is not very clear. The word paranakan is recorded in Old Javanese as one of the category watzk $i$ jro (insiders group in the court) (Zoetmulder 1982: s.v. paranakan). Zoetmulder also notes that in van der Tuuk's Balinese dictionary, pranakan means the student of a pandit. The reduplication of a prefix often means "resembling". Is what is meant that it resembles the shape of a paranakan, or that it resembles the way that paranakan paint? It seems that the latter is more plausible.

13. Mangin haris. Mamat Sasmita interprets this motif as a gentle wind. If it is applied to the decorations on the cloth, I suspect that the resulting motif is like thin waves.

14. Siliganti (ms. 624: salin gati). Mamat Sasmita leaves this motif uninterpreted. Nevertheless, it means "taking turns, one after another." Does this mean a motif that alternates between the warp and weft threads?

15. Boéh Siang. Mamat Sasmita is of the view that this term refers to a redcoloured cloth. The term siang is still known in Kanekes (Baduy) as a word for the colour red. It is said to be taboo to utter this word.

16. Beubeur natan. Mamat Sasmita does not interpret this shape as he considers bebernatan to be one word. The base word bernat is not found in the dictionaries. Therefore it should probably not be derived from the base word bernat, but rather explained as two words beubeur "tie" and natan "continuously, simultaneously" (Hardjadibrata 2003: s.v. natan). Perhaps this word refers to the technique of tying the cloth during the dyeing process in a simultaneous manner. Or maybe the shape of a waistband (beubeur in modern Sundanese) without a tied edge?

17. Papakanan. Mamat Sasmita concludes that papakanan tends to refer to an illustration of a bird feeding its young, based on the modern Sundanese word pakanan which means a mother bird feeding its young.

18. Surat awi. Mamat Sasmita interprets this as connotating the shape of the motif as a bamboo stem (Sundanese: awi) which is clearly visible when the sheath of the bamboo is removed beforehand. Or perhaps it should rather be read awi surat, a kind of bamboo that is large and 
thick, a variety of awi gedé, which indeed contains fibres that are clearly visible.

19. Parigi nyéngsoh. According to Mamat Sasmita, parigi refers to a wide flowing body of water, while nyéngsoh means "crooked." If that is correct, this term may refer to a cloth pattern like flowing water, depicted as winding like the batik motif léréng.

20. Gaganjar. Mamat Sasmita does not identify this motif. In Old Javanese, Wisseman Christie (1993) mentions gañjar patra as a pattern of offering cloth, translating gañjar as an object for a ritual offering. However, Zoetmulder records cun gañjar as a kind of eggplant. This possibility cannot be disregarded.

21. Lusian besar. Lusi (warp) is the thread that runs parallel to the weaver's legs. According to Mamat Sasmita, besar carries the meaning of Indonesian besar (large). Therefore, according to him, this motif is the same as poléng except that its warp is thicker than its weft. I propose the alternative possibility that besar may be parallel to the word basar in Old Javanese, one of whose meanings is "silk" (Zoetmulder 1982: s.v. basar). It may have a connection to the combination of materials, such as in songket, with cotton in the weft and silk in the warp.

22. Kampuh jayanti. Kampuh, according to Mamat Sasmita, means a blanket. So, kampuh jayanti means a blanket with a jayanti (Sesbania sesban) leaf or flower motif.

23. Hujan riris. In the dictionary, as noted by Mamat Sasmita, riris means 'fine or small'. Hujan riris means drizzling rain. In Java, the udan riris batik pattern is still known.

24. Boéh alus. Alus means fine. Mamat Sasmita interprets this as a fine cloth, such as silk.

25. Ragén pangantén. Mamat Sasmita is of the view that ragén pangantén refers to the name of a kind of plant that is otherwise known as ki rapet. He interprets this motif as a particular tree belonging to the dogbane family (namely Parameria laevigata) which grows close to others of its kind, like married couples (pangantén). My hypothesis is that perhaps this term does not refer to the motif, but to the colour, namely "marriage red," from ragi-an "(adj.) red, reddish," which might bear the connotation of the bride's blood on her wedding night.

Apart from the motifs or types mentioned above, in the Sri Ajnyana and Kawih Pangeuyeukan there are also mentions of several other motifs, such as:

1. Giringsing wayang. A double-ikat motif that is now only maintained in the village of Tenganan in Bali. Perhaps this double-ikat technique was once also practiced in Sunda. During the Majapahit period, 
the gringsing motif developed in East Java, as described in the Deśavarnana (18.4), but this seems unconnected to the double-ikat technique (Pigeaud 1960: 16, cf. Hall 2000:76). However, the motif is quite clear, it represents the wayang character.

2. Taluki wayang. Taluki means "fine cotton cloth (muslin)" (Zoetmulder 1982, s.v. taluki). Taluki wayang seems to mean a fine cloth with wayang character motifs.

3. Saca déwangga. This literally means "to approach the body of the deity." Zoetmulder also records dewänga in the sense of 'a kind of (red?) silk cloth'. Perhaps this cloth is meant to resemble the dewänga cloth.

4. Puyuh ngungkung. Puyuh is the name of a species of buttonquail (Turnix taigaor), while ngungkung has two meanings in Modern Sundanese. The first is "to pronounce the sound kung"; the second is "to be in a cage, unable to move." Often the context of the sentence mentions that this imagery is located on the uppermost edge of the cloth, so the first meaning is more plausible, that is, a buttonquail who seems to be chirping "kung."

5. Merak simpir. Literally this means "a peacock swiping to the side," perhaps referring to a depiction of a peacock running while swishing its wings.

6. Singa patra. Literally this means "leaf lion," perhaps what is meant is a lion who hides among the foliage or undergrowth. It is also possible to read śiwapattra (considering interchangeable case of $\dot{n}$ and $v$ in OldSundanese akșara), attested in Old-Javanese inscriptions (Zoetmulder 1982: s.v. śiwapattra). The meaning of śivapattra in Sanskrit is "red lotusflower," but in Old Javanese it refers to a type of weapon (a dagger?).

\section{The Supernatural Aspects of Weaving}

Understanding weaving traditions of the archipelago in the past cannot be separated from the mystical elements surrounding them. Hauser-Schäublin et al. in their book entitled Balinese Textiles even mention that in Bali, woven cloths "are a medium through which the divine nature of the universe and its material manifestations are recognised and expressed" (1991: 8). A more or less similar situation prevailed in the Sundanese regions at least up to the 17th century, or perhaps even to the present day, but limited to Kanekes, where traditional weaving practices have been maintained. Various aspects of premodern Sundanese cosmology, and concepts about the world of divinities, can be discovered through a unique text entitled Kawih Pangeuyeukan (Weaving Songs), an Old Sundanese poem written no later than the 17th century. This text seems to have been intended "to be sung while weaving" (pikawiheun bwat ngeuyeuk) by women, and provides an indication that probably women participated in Sundanese written culture, as this tradition was exclusively 


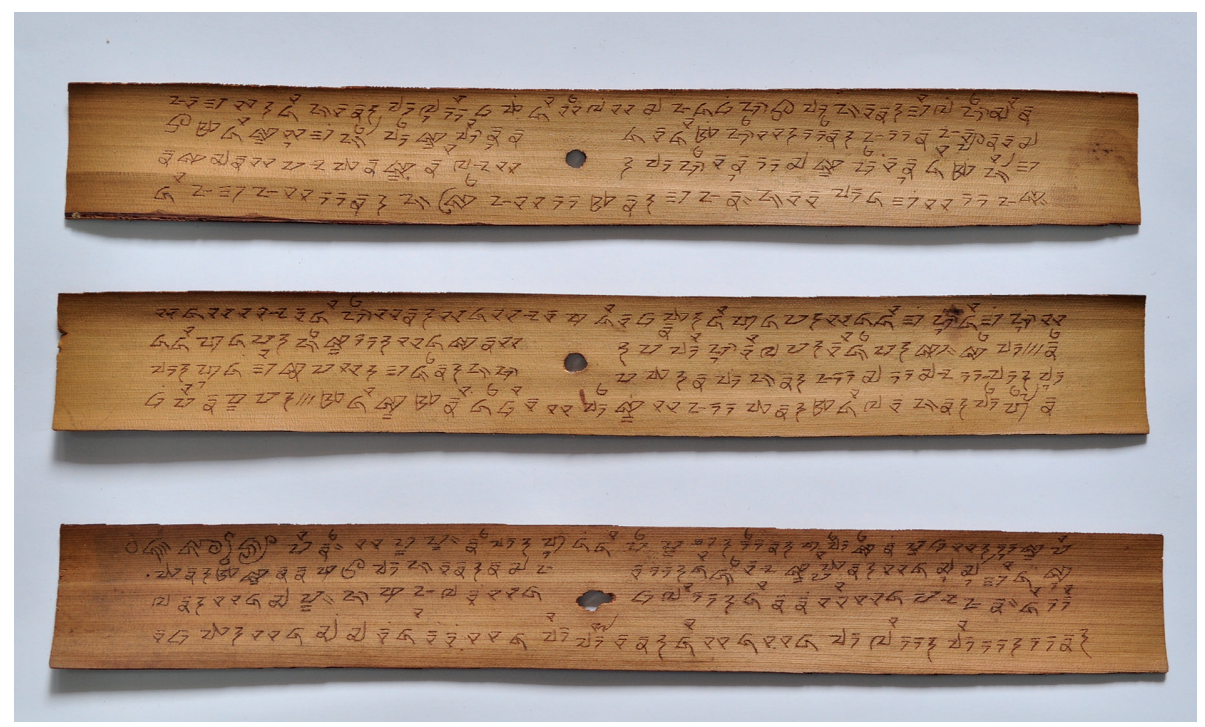

Fig. 3 - Ms. L 407, Kawih Pangeuyeukan (National Library of Indonesia)

practiced by women.

The text Kawih Pangeuyeukan reveals how powerful the spiritual and symbolic aspects of weaving were. One feature suggesting that weaving was included in sacred religious rituals is the mention of parawanten and kukus, in conjunction with the goddesses who resided in both of those objects. Parawanten are the materials for offerings, which cannot be separated from kukus, the smoke of incense. The goddesses who reside in the parawantan are Manik Sari, Sari Déwata, and Maya Hibar, while the goddess who resides in incense smoke is Banan Sakti. Furthermore, a scene in which Raden Jaya Keling commands his wife to clean her body with water and to purify her inner blemishes before weaving (ruat mala) suggests that weaving activities involved exorcism rituals. On this basis, it can be asserted that weaving constituted a sacred ritual that involved the netherworld.

According to the myth contained in the Kawih Pangeuyeukan, weaving began with the creation of the universe. Aci Déwata (which means "the divine essence"), the leader of the deities, ordered his subordinate goddesses to fill the world so that it would become bustling, for beforehand the world was still empty, without water or firmament, without light in the sky, and there were no clouds; everything was scattered and out of place. That is what was called the origin of clarity. Groups of goddesses collectively called aksari and pwah aci descended from the heavens to the earth with goodwill, but they did not want to stay long. Aci Déwata invited the goddesses to go back to the world for a longer time. She summoned around 25 female heavenly beings (betari, 
aksari and pwah aci). The younger sister of Aci Déwata, namely Sang Hyang Sri, invited all the goddesses to descend again to the earth. In a new place they amused themselves and relaxed. This place where the heavenly women resided is associated with weaving, including the materials, processes, tools, and the body of the weaver herself.

We are dealing with a kind of feminine creation myth. The heavenly female figure who is the origin and essence of all events is Sang Hyang Sri. She is the ultimate goddess who is the efficient cause for all life in the world, including the practice of weaving. Her place in the world of the gods (kahyangan) is called Bungawari (SD.59), the highest position within the cosmology of goddesses. This name, none other than that of the plant bunga wari (Tabernaemontana difaricata), is interesting because it is the raw material for the production of cloth and is a synonym of kapas (SSMG.39).

Sang Hyang Sri and her retainers, who are all women, represent the macrocosm. They are all manifested in the weaving tools that are likewise used exclusively by women. And the weaver's own self represents the microcosm. In other words, the process by which the macrocosm (the world of the goddesses) becomes manifest in the microcosm (the weaver) is through a ritual of weaving that was practiced by Sundanese women in their daily lives. This situation apparently continues to this day in Baduy, where weaving is considered as a part of ascetic practice recognized in local customary law (pikukuh) (Nina Maftukha et al. 2017: 54).

In connection with ascetic rituals to achieve moksa (liberation), the voice of the weaver can act as a sign. In the Kaputusan Sang Hyang (2.6-3.7), ${ }^{33}$ for example, it is explained that the complete time frame for performing austerities is seven years. If the buzzing of bees is heard, it means that then seven years of austerities remain. If the sound of someone weaving is heard, then the remaining time is three years, and if the person weaving is heard to be approaching, then the remaining time is only one more year.

ini paké nyeueung na patengeran nu siya guna tapa, kadéngé sada sééng sahéng, sada odèng pindah, tujuh tahun deui pulang; ka deukeutna, lima tahun deui pulang; kadéngé sada ketig, sada ketug, telu kali, lima tahun deui pulang; ka deukeutna telu tahun deui pulang; kadéngé sada nu neupa, sada nu ngawih, tilu tahun deui pulang, ka deukeutna satahun deui pulang.

Use this [sign] to indicate to anyone who is performing austerities: if the sound of a bubbling pot or the sound of moving bees is heard, one can go home (i.e. achieve liberation) in seven more years; if [the sound] gets closer, five more years; if the

33. MS. Cod. Peti 89 no. 280 of the National Library of Indonesia. This manuscript is a transcription in Latin script done by Holle, based on the Ciburuy MS no. 8. The original manuscript, which must have been written in Old Sundanese characters, has not been identified either in the collection of the National Library or in the extant Ciburuy collection. 
sounds of knocking and tapping are heard, one can go home in five more years; if [the sound] gets closer, one can go home in three more years; if the sound of someone weaving or the sound of someone humming is heard, one can go home in three more years; if [the sound] gets closer, one can go home in one more year.

In other texts with a more masculine character, such as the Pituturning Janma (Cod. L 610, National Library of Indonesia), the gods occupy the male parts of the body, whereas in the feminine Kawih Pangeuyeukan, we find betari, pwah aci, pwah sari and aksari occupying the female parts of the body (namely, the womb and breasts). Interestingly, the first name of each of the goddesses is affixed with the honorific name Pretiwi (lit.: Earth) (see Table 1 below).

Table 1 - The goddesses and their location in the female body according to the Kawih Pangeuyeukan

\begin{tabular}{|l|l|l|}
\hline No & Name & Place in the body \\
\hline 1 & Pretiwi Tamba Kanda & Face \\
\hline 2 & Pretiwi Dasar Jati & Soles of the feet \\
\hline 3 & Pretiwi _-_ ${ }^{34}$ & Breasts \\
\hline 4 & Pretiwi Yuga Bwana & Right part of the womb \\
\hline 5 & Pretiwi Yuga Akasa & Left part of the womb \\
\hline 6 & Pretiwi Mutiya Cita & Heart \\
\hline 7 & Pretiwi Lengis Jati & Tips of the hair \\
\hline 8 & Pretiwi Harémpoy Jati & Raunan (bones?) \\
\hline 9 & Pretiwi Hiret Jati & Eyeballs \\
\hline 10 & Pretiwi Hines Jati & Eyelids \\
\hline 11 & Pretiwi Mukadandana & Mantungan (?) \\
\hline
\end{tabular}

In this text we also find identified around 43 names of betari, pwah aci or aksari who reside in the raw materials required for weaving. In some cases the connection between the names of the divine beings and their place of residence is easily comprehensible. The name Pohaci Tunjung Mangbang (Red Lotus), for example, is metaphorically associated with red cloth, Cita Putih (White Heart) is associated with white cloth, Nila Keling (Dark Keling) is associated with black cloth. But most names are assigned in what appears to be an arbitrary manner.

$\overline{\text { 34. Three aksaras }}$ are missing in the manuscript and cannot be reconstructed. 
Table 2 - The pwah aci and aksari (goddesses) and their places of residence in weaving materials and cloth

\begin{tabular}{|c|c|c|}
\hline No & Name of Pwah Aci/Aksari & Place of residence \\
\hline 1 & Naga Susupan & Woof yarn \\
\hline 2 & Tunjung Putih & Cotton tree \\
\hline 3 & Tunjung Manik & Cotton tree fruit \\
\hline 4 & Sang Hyang Jipang & Kapok tree \\
\hline $\begin{array}{l}5 \\
6 \\
7 \\
8 \\
\end{array}$ & $\begin{array}{l}\text { Cita Manik } \\
\text { Tunjung Putih } \\
\text { Maya Sri Séda } \\
\text { Naga Wana }\end{array}$ & Yarn (kantéh) \\
\hline $\begin{array}{l}9 \\
10\end{array}$ & $\begin{array}{l}\text { Cita Manik } \\
\text { Cita Putih }\end{array}$ & White cloth \\
\hline $\begin{array}{l}11 \\
12 \\
13 \\
\end{array}$ & $\begin{array}{l}\text { Tunjung Mangbang } \\
\text { Mangbang Siang } \\
\text { Mabar Sari }\end{array}$ & Red cloth \\
\hline $\begin{array}{l}14 \\
15 \\
16\end{array}$ & $\begin{array}{l}\text { Sahipes Jati } \\
\text { Nila Keling } \\
\text { Kembang Wisésa }\end{array}$ & Black cloth \\
\hline 17 & Tunjung Kuning & Yellow cloth \\
\hline $\begin{array}{l}18 \\
19\end{array}$ & $\begin{array}{l}\text { Ceunteu Rupa } \\
\text { Cida Sari }\end{array}$ & Teureus cloth (that is being dyed?) \\
\hline 20 & Tunjung Biru & Blue cloth \\
\hline $\begin{array}{l}21 \\
22 \\
23\end{array}$ & $\begin{array}{l}\text { Sarba Mayang } \\
\text { Sarba Éndah } \\
\text { Sarba Larang }\end{array}$ & Multicoloured cloths \\
\hline 24 & Aci Sakti & Yellow cloth (tuar) \\
\hline $\begin{array}{l}25 \\
26 \\
27\end{array}$ & $\begin{array}{l}\text { Ringgit Sari } \\
\text { Maya Aci Désa } \\
\text { Maya Réka }\end{array}$ & Strong thread \\
\hline $\begin{array}{l}28 \\
29 \\
\end{array}$ & $\begin{array}{l}\text { Gagana Jati } \\
\text { Sari Aci }\end{array}$ & Green curtain \\
\hline 30 & Aci Wisésa & Yellow curtain \\
\hline 31 & Sari Aci Rupu & Curtain of other colours \\
\hline $\begin{array}{l}32 \\
33 \\
\end{array}$ & $\begin{array}{l}\text { Cita Manik } \\
\text { Sang Hyang Sri }\end{array}$ & The left hand \\
\hline 34 & Cita Hanteu & sunya larang (kind of motif?) \\
\hline 35 & Hurip Jati & The dyer (nu molah) \\
\hline $\begin{array}{l}36 \\
37 \\
\end{array}$ & $\begin{array}{l}\text { Harenang Harening } \\
\text { Lénggang Manik }\end{array}$ & The weaver (nu ngeuyeuk) \\
\hline 38 & Aci Wisésa & $\begin{array}{l}\text { White curtain (the scriber seems to } \\
\text { repeat this name, see no. } 30 \text { above) }\end{array}$ \\
\hline
\end{tabular}




\begin{tabular}{|l|l|l|}
\hline 39 & Aci Mirah & Red curtain \\
\hline 40 & Naga Langgusar & Woven cloth \\
\hline 41 & Naga Lenditan & Weft yarn \\
\hline 42 & $\begin{array}{l}\text { Naga Mapwaday } \\
\text { Maga Maredaya }\end{array}$ & $\begin{array}{l}\text { Pattern (to work on) of a weave } \\
\text { design (check pattern) (Tingkes) }\end{array}$ \\
\hline
\end{tabular}

What is exceptional about the Kawih Pangeuyeukan is the placement of the goddesses' abodes among the different parts of the weaving process. In this way, we obtain valuable information about the instruments used for weaving in Tatar Sunda in the 17th century. Many of the terms are still known in modern Sundanese. Below I present the names of the weaving instruments as mentioned in the text, their identification, as well as the goddesses who are responsible for them.

Table 3 - Weaving instruments and the goddesses who reside in them, based on the Kawih Pangeuyeukan

\begin{tabular}{|c|c|c|}
\hline Instrument & $\begin{array}{l}\text { Explanation from Modern } \\
\text { Sundanese Sources (MdS) }\end{array}$ & Name of Pwah aci/Pwah Sri \\
\hline Jujutan & $\begin{array}{l}\text { Cotton that has been removed from } \\
\text { its sheath and seeds. The verb, } \\
\text { ngajujut (MdS), means to separate } \\
\text { cotton from its sheath and pod } \\
\text { (Hardjadibrata, s.v. jujut). }\end{array}$ & $\begin{array}{l}\text { Pijeyah Jati, } \\
\text { Sang Drawada, } \\
\text { Sang Weredin }\end{array}$ \\
\hline Hindesan & $\begin{array}{l}=\mathrm{MdS} \text {, a tool for processing cotton } \\
\text { to separate it from its seeds (KUBS, } \\
\text { s.v. hindesan) }\end{array}$ & Kowari Jati, Gilingan Jati \\
\hline Kincir & $\begin{array}{l}=\text { MdS, spinning wheel, or spindling } \\
\text { wheel, a tool for rolling yarn. The } \\
\text { spokes of the wheel are called daun } \\
\text { rahat in Indonesian. }\end{array}$ & Peningan Jati \\
\hline Eunteung kincir & $\begin{array}{l}=\mathrm{MdS} \text {, two posts to hold the ceuli } \\
\text { lambing that faces the kincir. }\end{array}$ & Mangadeg Jati \\
\hline Ceuli Lambing & $\begin{array}{l}=\text { MdS, two pegs to hold the injén } \\
\text { "axis" of the eunteung kincir that } \\
\text { are joined with a kisi and function } \\
\text { as spindles (see Hardjadibrata, s.v. } \\
\text { ceuli) }\end{array}$ & Talinga Jati \\
\hline Kisi & $\begin{array}{l}=\mathrm{MdS} \text {, the axis of the spindle that } \\
\text { is used to spin the yarn or to insert a } \\
\text { palette of a roll of thread. }\end{array}$ & Tandingan Jati \\
\hline Hasiwung & $\begin{array}{l}\text { A cotton roll that has been cleaned } \\
\text { and is ready to be turned into yarn = } \\
\text { MdS asiwung. }\end{array}$ & $\begin{array}{l}\text { Déwa Carita } \\
\text { Sri Manglayang }\end{array}$ \\
\hline Layeutan & $\begin{array}{l}\text { A tool for stretching out thread to } \\
\text { prevent tangling. Not recorded in } \\
\text { the dictionaries. }\end{array}$ & $\begin{array}{l}\text { Tunjungan Jati } \\
\text { Naga Sampayan } \\
\text { Maung Larang }\end{array}$ \\
\hline
\end{tabular}




\begin{tabular}{|c|c|c|}
\hline Sikat & $\begin{array}{l}=\mathrm{MdS} \text {, a comb-like tool for } \\
\text { straightening out the fibres on the } \\
\text { loom. }\end{array}$ & Pamérés Jati \\
\hline $\begin{array}{l}\text { Undar-andir } \\
\text { (MS: urar-adir) }\end{array}$ & $\begin{array}{l}=\text { undar (MdS), handle of the } \\
\text { kéncéh (cylindrical stick of wood or } \\
\text { bamboo) }\end{array}$ & $\begin{array}{l}\text { Mangbang Bwana } \\
\text { Peningan Jati }\end{array}$ \\
\hline Ulakan & $\begin{array}{l}\text { = elékan (MdS), thin bamboo } \\
\text { (usually Schizostachyum blumei) } \\
\text { for twisting yarn. }\end{array}$ & Sideg Jati \\
\hline Pihanéan & $\begin{array}{l}=\text { MdS, a tool resembling a drying } \\
\text { rack, to stretch out the yarn for } \\
\text { weaving, usually made of bamboo. }\end{array}$ & $\begin{array}{l}\text { Mangbang Désa } \\
\text { Widadasana }\end{array}$ \\
\hline Sawung & $\begin{array}{l}\text { Not yet identified, perhaps } \\
\text { identifiable as MdS saung "a } \\
\text { pavilion," where weaving is done? }\end{array}$ & Héno Raja \\
\hline $\begin{array}{l}\text { Celi? (MS: cali } \\
\ldots \text { ?) }\end{array}$ & $\begin{array}{l}\text { Not yet identified, and the text is } \\
\text { damaged. }\end{array}$ & Ménget Jati \\
\hline Galégéran & $\begin{array}{l}=\mathrm{MdS} \text {, a warp-tie that acts as the } \\
\text { bottom edge of the woven cloth. } \\
\text { The galegeran sits above the } \\
\text { dampal. The opposite side of the } \\
\text { hapit. }\end{array}$ & Pamineng Jati \\
\hline Sumbi luput & $\begin{array}{l}=\text { MdS, a kind of nail used to } \\
\text { strengthen the loom. }\end{array}$ & ? (the text is damaged) \\
\hline Hapit & $\begin{array}{l}=\mathrm{MdS} \text {, a piece of wood that sits } \\
\text { on the weaver's thighs to roll the } \\
\text { woven cloth. }\end{array}$ & Naga Wiru \\
\hline Parérédan & $\begin{array}{l}\text { = baréra (MdS), a slice of thin } \\
\text { wood (a weaving sword) for } \\
\text { tightening the weft threads that } \\
\text { are braided through the warp. Old } \\
\text { Javanese walira "part of a weaver's } \\
\text { loom (a stick or bow) with which } \\
\text { the threads are pressed together." }\end{array}$ & Masangga Jati \\
\hline Pangulas & $\begin{array}{l}=\mathrm{MdS} \text {, a brush used to smear water } \\
\text { on the woven cloth. }\end{array}$ & Sarampéh Jati \\
\hline $\begin{array}{l}\text { Tungtung } \\
\text { Pangulas }\end{array}$ & The edge of the brush. & Cuuh Ibun \\
\hline Sumbi & $=\mathrm{MdS}$, the spindle of the loom. & Naga Gégéntar \\
\hline Laki Pihanéan & $\begin{array}{l}=\mathrm{MdS} \text {, a kind of pestle used to } \\
\text { weight the yarn on the pihanéan } \\
\text { so that the threads stay straight and } \\
\text { do not tangle; while the pihanéan } \\
\text { itself is a tool for straightening and } \\
\text { stretching out yarn that will later } \\
\text { become the warp of the gedogan. }\end{array}$ & Balabar \\
\hline
\end{tabular}




\begin{tabular}{|c|c|c|}
\hline Piseureungan & $\begin{array}{l}=\mathrm{MdS} \text {, a small basket for storing } \\
\text { sundry weaving tools. }\end{array}$ & $\begin{array}{l}\text { Mutaya Jati } \\
\text { Naga Sumara } \\
\text { Naga Kumpulan }\end{array}$ \\
\hline Lorogan & $\begin{array}{l}=\text { MdS, a piece of wood for holding } \\
\text { the baréra fast as it is being } \\
\text { inserted. Sits on the right hand side } \\
\text { of the weaver. }\end{array}$ & Malawading \\
\hline Caor & $\begin{array}{l}=\text { MdS, a part of the gedogan, in } \\
\text { the form of a board attached behind } \\
\text { the weaver's waist, connected } \\
\text { to the hapit using a tali caor } \\
\text { (Hardjadibrata, s.v. caor). }\end{array}$ & Naga Dadampar \\
\hline Tali Caor & $\begin{array}{l}=\mathrm{MdS} \text {, a piece of thread connecting } \\
\text { the caor and the woven cloth, on } \\
\text { both the left and right hand sides of } \\
\text { the weaver. In the } L K \text {, the highest } \\
\text { quality is spinning-wheel wire or } \\
\text { kenur cina. }\end{array}$ & Naga Pawilet \\
\hline Limbuhan & $\begin{array}{l}=\mathrm{MdS} \text {, a cylindrically-shaped piece } \\
\text { of wood to weight the warp, which } \\
\text { is allowed to stay caught among } \\
\text { the warp threads (Hardjadibrata, } \\
\text { s.v. limbuh), forming a part of the } \\
\text { gedogan. In DK, the high-quality } \\
\text { examples come from Nusa Galuh. }\end{array}$ & Naga Mangguling \\
\hline Jingjingan & $\begin{array}{l}=\text { MdS, a large needle, } \\
\text { approximately one metre in length, } \\
\text { made of bamboo or a tree branch, to } \\
\text { take or lift the thread and to regulate } \\
\text { the rise and fall of the warp that } \\
\text { will be threaded by the weft. See } \\
\text { Danadibrata, s.v. jingjing. In DK, } \\
\text { the high-quality examples come } \\
\text { from Nusa Galuh. }\end{array}$ & Naga Mangi... \\
\hline Karap & $\begin{array}{l}\text { (= MdS, Indonesian suri) is a fine } \\
\text { comb attached to the loom that } \\
\text { serves to arrange the lines of the } \\
\text { warp so that they can be easily } \\
\text { shifted by the movements of the } \\
\text { jingjingan. }\end{array}$ & Sang Suwar Jati \\
\hline Peténg & $\begin{array}{l}=\mathrm{MdS} \text {, a weaving tool that is used } \\
\text { to arrange the cotton rolls into fine } \\
\text { fibres. The verb, dipeténg (passive), } \\
\text { means to be arranged into fine fibres } \\
\text { before becoming yarn. }\end{array}$ & $\begin{array}{l}\text { Timbul Manik } \\
\text { Mangyupuk Putih } \\
\text { Maya Métar }\end{array}$ \\
\hline
\end{tabular}




\begin{tabular}{|l|l|l|}
\hline Kéncéh & $\begin{array}{l}\text { = MdS, a part of the undar shaped } \\
\text { like a square spool that spins } \\
\text { horizontally. The undar spins when } \\
\text { the spool is turned and the thread on } \\
\text { the kéncéh is transferred into a roll } \\
\text { on the palette. Could it be the same } \\
\text { as the "leaf"? }\end{array}$ & Naga Langsaran \\
\hline Lawayan & $\begin{array}{l}\text { = MdS, a roll of yarn or spool, made } \\
\text { of bamboo to orient the cotton } \\
\text { thread towards the gelendong. See } \\
\text { Hardjadibrata (2003, s.v. laway). }\end{array}$ & Kéncéngan Jati \\
\hline
\end{tabular}

Finally, it should be added that the Kawih Pangeuyeukan mentions various goddesses with responsibilities in the weaving process, from the cotton that is dried, rolled and stretched out, to its preparation on the heuyeuk (weaving loom). But this process seems to be associated only with the production of yarn up to its placement on the loom, and does not include the process of dyeing and ikat-weaving.

\begin{tabular}{|c|c|c|}
\hline No & Name of Goddess & Process \\
\hline 1 & Daranan Manik & Drying (dipoé) \\
\hline 2 & Sri Seda Mangrincik & The cotton is rolled on a hindesan (dihindesan) \\
\hline 3 & Sang Kuna Jati & Cleaning coarse cloth with peténg (dipeténg) \\
\hline 4 & Gilingan Manik & Being grinded (digiling) \\
\hline 5 & Kecelan Jati & Being brushed (disikat) \\
\hline $\begin{array}{l}6 \\
7\end{array}$ & $\begin{array}{l}\text { Mangbang Désa } \\
\text { Sampayan Jati }\end{array}$ & Being stretched out (dipentang) \\
\hline 8 & Tunjung Manik & When (the cotton) it is opened (ngaran basana dibuka) \\
\hline 9 & Naga Maruway & The kantéh is placed on the gedogan \\
\hline 10 & Naga Numpi & $\begin{array}{l}\text { Preparing thread until it is dry without sunlight } \\
(\text { dipendac })^{35}\end{array}$ \\
\hline
\end{tabular}

As the skill of tapping the areca palm for men, for women weaving was a form of activity that involved the netherworld. The ability to weave was a sign of a woman's maturity, while for men, adulthood was marked by their ability to tap the palm. This fact is illustrated perfectly in a Sundanese satirical verse (sisindiran) that remained in use up to the beginning of the 20th century as recorded in Pleyte (1912).

35. This word seems to have become the Modern Sundanese pendat. The word pendat is only recorded in Coolsma (1913, s.v. pendat), according to which source it means to prepare thread until it is dry without sunlight. Regarding the relationship between the phonem $/ \mathrm{t} / \mathrm{l}$ at the end of a word in Old Sundanese and the sound $\mathrm{t}$ in Modern Sundanese, see the linguistic summary in Noorduyn \& Teeuw (2006: 29-112). 
ulah sok hayang ka gulaDon't wish for sugar

Tacan bisa ninggur kawung if one can't tap a sugar palm tree

Ulah sok hayang ka kula

Don't wish for me

Tacan bisa ninun sarung

Before you can weave a sarong.

Apart from that, in the Cirebon version of the Lutung Kasarung, for example, we find a depiction of when Lutung, who is none other than a manifestation of Guru Minda in heaven, descends to earth to find a soulmate. In a certain palace he finds some young women who are weaving. He spies on them, but he cannot find a single one who resembles his mother, whose beauty cannot be forgotten.

geledeg lumpat, bus $k a$

kolong balé

empés-empés ngadédéngékeun,

ngintip para mojang,

nu lalenjang

keur pada ngagembrong ninun. Who were busy weaving in a circle

Nya ninun wulung digantung,

nya tinun poléng digédéng.
Then he fled into a space beneath the pavilion

Staying put while eavesdropping

Spying on the slender women

Weaving dark blue cloth to be hung up

Weaving poléng cloth to be lined up.

Other mythical aspects of weaving are also a common theme in the oral traditions. For example, in descriptions of weaving in carita pantun, there is always an explanation of taboos concerning the disposal of ceuceupan (dyeing water) which, if transgressed, will bring bad luck. This issue is covered in the Demung Kalagan and the Radén Tegal which I quote in full below.

tutas nyai titinunan,

lajeng baé tinun dilulunkeun, ceuceupanna dibahékeun, piseureunganna ${ }^{36}$ diampihan, bok bilih dilétak méong, watekna da cenah, sok hambur kana pakan, atanapi watek jahat, nu mawi rék dirawat.
After Nyai had woven, and the cloth was rolled up, the dyeing water was poured out, the basket was put in order, lest it be lapped up by the cat, because it is said that it causes warp to be wasted, or an evil disposition, that is why it should be taken care of.

(DK.60)

36. The transcription reads piseureunna. 
tinun dilanggurupkeun, ari indit ngusap birit,

bisi birit maheum samping, ja larangan budak ngora,

cipangulas dibaturkeun, nya bisi ditotor méong, kajeun teuing, bisi dikojayan anja-anja .
The woven cloth is laid down, One wipes one's buttocks and inches away, The buttocks may pinch the cloth, For as a thing that children should not touch, The dyeing water is placed up high, But lest it be drunk by the cat, Just leave it alone, Lest it be crossed by ghosts.

(RT.53)

The myth about weaving found in the carita pantun above seems to have been well-known at the time of its recording. Apart from the carita pantun, in the folk tale of Nini Antéh which has turned into legend, there is also an illustration of a pantrangan (taboo) for a slovenly person. This sacred fable tells of a cat who ends up pregnant after drinking urine from a coconut shell.

Other supernatural aspects of the weaving process include the use of jampé or mantras while weaving. ${ }^{37}$ Besides the goddesses, the one who occupies the highest place and whose protection is requested during weaving is Pohaci Wiru Mananggay, the goddess who was apleased in mantra recitation during the weaving (see Pleyte 1912: 50). In the Sri Ajnyana, it is explained that this goddess resides in a place called Sari Déwata. In this Śaiva text, Wiru Mananggay decides not to marry and chooses to live as a tiagi (female ascetic). She uses a heuyeuk (weaving tool) as her guide for life (SA.938-944):
datang ka sari déwata,
Arriving in the Divine Essence, geusanna wiru mananggay, The abode of Wiru Mananggay, deung nu bagal nanding larang, And Bagal Nanding Larang, nu watek titiagian, Who practiced asceticism, meuyeut manéh mo lakian, Torturing herself by not marrying, heuyeuk dipaké nyanggraha, hanteu dipikatresna.
She uses the loom as her aid, Having no amorous passion.

Another being who is influential in the weaving process is Banaspati. Just as Kala and Udubasu during the land-clearing, ${ }^{38}$ Banaspati needs to be appeased before someone starting to weave. According to Sundanese belief, Banaspati is a female spirit who lives in the forest tree-tops while making yarn (kantéh) (Hardjadibrata 2003: 65; Danadibrata 2006: 58-59). She is believed to be a

37. Pleyte (1912) notes at least ten differents mantras during the weaving production.

38. The oldest evidence of a land clearing involving Kala and Udubasu in West Java may be the one found in Huludayeuh inscription (Aditia Gunawan \& Arlo Griffiths, forthcoming). 
disruptive spirit who causes people to become ill. In Old Sundanese beliefs as reflected in the Sang Hyang Raga Déwata (fol. 18-19), if someone is ill due to the action of Banaspati, various cleansing aids must be prepared, such as fried shrimp, cooked fish and raw chicken, as well as provisions coloured red and yellow.

It is clear that weaving itself required preparatory rituals of appeasement, in order to avoid any kind of disturbance. Sakéan Adi Larangan, the protagonist of the Kawih Pangeuyeukan, having dreamed of hearing the scream of Banaspati in her sleep, seemed to get bad symptoms. Her husband Jaya Keling immediately instructed his wife to go to the river and scrub all the parts of her body as an aid in eliminating the ten defilements (dasakalésa).

tinun dara dianggeuskeun, kéna réa na rancana, bancana sapoyan aing, los ta geura nu ka cai, geura nu diangir mandi,

mésék ngabreséka manéh, ngaruru dimangka kabéh, pamocoran dasakalésa.
Do not complete your weaving! Because of all of her provocations, The disaster I feared [has occurred] Go quickly to the river!

Bathe and soap yourself straight away!

Cleanse yourself!

Scrub every part of your body!

As a means to wipe out the ten defilements.

KP.98-105

\section{Conclusion}

The data presented above give a picture of the types of textile production and their functions in Sundanese society from the 15th to the 17th centuries. Based on local sources from Old-Sundanese texts and carita pantun, various activities surrounding fabric production have also been described, ranging from colouring fabrics to the production of motifs. In the context of pre-Islamic Sunda, one of the most popular techniques for producing cloth was through the process of ikat weaving - a tradition which has now become extinct, replaced by more modern factory production of textiles. The practice of weaving also cannot be separated from its supernatural aspects. Through textual sources, we have learned about the cosmological associations of the primary colours, which are applied to fabric by various dyeing agents. The practice of weaving itself was associated with ritual activity that involved the netherworld. Various ritual aids were prepared, various disturbances were driven far away using pacificatory rituals, and mantras were pronounced in order to avoid trouble. In addition to fulfilling daily/profane needs, the complex activity of weaving, which was intimately connected to the netherworld, allowed Sundanese women to practice a form of asceticism entirely integrated with worldly life. 


\section{Bibliography}

Acri, Andrea, and Arlo Griffiths. 2014. "The Romanisation of Indic Script Used in Ancient Indonesia." Bijdragen tot de Taal-, Land- en Volkenkunde 170 (2-3): 365-78. https://doi. org/10.1163/22134379-17002005.

Aditia Gunawan. 2009. Sanghyang Sasana Maha Guru dan Kala Purbaka: Suntingan dan Terjemahan. Jakarta: Perpustakaan Nasional Republik Indonesia.

- 2010. "Warugan Lemah: pola permukiman Sunda Kuna." In Perubahan Pandangan Aristokrat Sunda dan Essai-essai lainnya mengenai Kebudayaan Sunda, 147-81. Sundalana 9. Bandung: Pusat Studi Sunda.

—. 2015. "Nipah or Gebang? A Philological and Codicological Study Based on Sources from West Java." Bijdragen tot de Taal-, Land- en Volkenkunde 171 (2-3): 249-80. https://doi. org/10.1163/22134379-17101004.

Aditia Gunawan, and Arlo Griffiths. Forthcoming. "Old Sundanese Inscriptions."

Ajip Rosidi, ed. 1970. Tjarita Demung Kalagan dipantunkeun ku Ki Kamal (Lebakwangi, Kuningan). Bandung: Proyek Penelitian Pantun dan Folklor Sunda.

Atja, and Saleh Danasasmita. 1981a. Carita Parahiyangan (Transkripsi, Terjemahan dan Catatan). Bandung: Proyek Pengembangan Permuseuman Jawa Barat.

—, eds. 1981b. Sanghyang Siksakanda ng Karesian (Naskah Sunda Kuno Tahun 1518 Masehi). Bandung: Proyek Pengembangan Permuseuman Jawa Barat.

Balogh, Dániel, Arlo Griffiths, and Axelle Janiak. 2019. "Transliteration Guide for Members of the DHARMA Project." https://halshs.archives-ouvertes.fr/halshs-02272407.

Buckley, Christopher. 2017. "Looms, Weaving and the Austronesian Expansion." In Spirits and Ships: Cultural Transfers in Early Monsoon Asia. Edited by Andrea Acri, Roger Blench, and Alexandra Landmann. 273-324. Singapore: ISEAS Publishing.

Cecep Eka Permana, R. 2006. Tata Ruang Masyarakat Baduy. Jakarta: Wedatama Widya Sastra.

Coolsma, S. 1913. Soendaneesch-Hollandsch woordenboek. 2nd ed. Leiden: Sijthoff.

Cortesão, Armando, ed. 1944. The Suma Oriental of Tomé Pires: An Account of the East, from the Red Sea to Japan, Written in Malacca and in India 1512-1515, and the Book of Francisco Rodrigues: Rutter of a Voyage in the Red Sea, Nautical Rules, Almanack and Maps, Written and Drawn in the East before 1515. Works Issued by the Hakluyt Society 2. London: Hakluyt Society.

Damais, Louis-Charles. 1969. "Études Javanaises, III: A propos des couleurs symboliques des points cardinaux." Bulletin de l'École française d'Extrême-Orient 56: 75-118.

Danadibrata, R.A. 2006. Kamus Basa Sunda. Edited by Ajip Rosidi. 1st ed. Bandung: Panitia Penerbitan Kamus Basa Sunda (Kiblat Buku Utama \& Universitas Padjadjaran).

Dewan Bahasa dan Pustaka, ed. 2005. Kamus Dewan. 4th ed. Kuala Lumpur: Dewan Bahasa dan Pustaka.

Eringa, F.S. 1984. Soendaas-Nederlands woordenboek: mede met gebruikmaking van eerder door R.A. Kern bijeengebrachte gegevens. Dordrecht [etc.]: Foris.

Gallop, Annabel Teh. 2013. "The Language of Malay Manuscript Art: A Tribute to Ian Proudfoot and the Malay Concordance Project." International Journal of the Malay World and Civilisation 1 (3): 11-27.

Goris, Roelof. 1954. Prasasti Bali. 2 vols. Bandung: N.V. Masa Baru.

Hall, Kenneth R. 2000. "Personal Status and Ritualized Exchange in Majapahit Java." Archipel 59: 51-96.

Hardjadibrata, R.R. 2003. Sundanese English Dictionary. Jakarta; Bandung: PT. Dunia Pustaka Jaya; Kiblat Buku Utama.

Hauser-Schäublin, Brigitta, Marie-Louise Nabholz-Kartaschoff, and Urs Ramseyer. 1991. Balinese Textiles. London: British Museum Publications. 
Holle, K.F. 1867. "Vlugtig berigt omtrent eenige lontar-handschriften, afkomstig uit de Soendalanden, door Raden Saleh aan het Bataviaasch Genootschap van K. en W. ten geschenke gegeven, met toepassing op de inscriptiën van Kwali." Tijdschrift voor Indische Taal-, Land-en Volkenkunde 16: 450-70.

Jákl, Jiří. 2016. "The Loincloth, Trousers, and Horse-Riders in Pre-Islamic Java: Notes on the Old Javanese Term Lañcinan." Archipel 91: 185-202. https://doi.org/10.4000/ archipel.312.

Jasper, J.E., and Mas Pirngadi. 1912. De inlandsche kunstnijverheid in Nederlandsch Indië. Vol. 2. 5 vols. 's-Gravenhage: Mouton.

Judistira Garna. 1987. Orang Baduy. Siri etnografi bergambar UKM. Bangi: Penerbit Universiti Kebangsaan Malaysia.

Jurusan Pendidikan Bahasa Daerah, Fakultas Pendidikan Bahasa dan Seni (FPBS), Universitas Pendidikan Indonesia. 2008. Palanggeran Éjahan Basa Sunda. 4th ed. Bandung: Sonagar Press.

Kern, Hendrik. 2015. Rāmāyaṇa: The Story of Rāma and Sìtā in Old Javanese. Edited by Willem van der Molen. Javanese Studies 1. Tōkyō: Research Institute for Languages and Cultures of Asia and Africa, Tokyo University of Foreign Studies.

Livingston, Judith H. 1994. "Ikat Weaves of Indonesia and India: A Comparative Study." India International Centre Quarterly 21 (1): 152-74.

Mamat Ruhimat, Aditia Gunawan, and Tien Wartini. 2014. Kawih Pangeuyeukan: Tenun dalam Puisi Sunda Kuna dan Teks-teks lainnya. Seri Naskah Kuna Nusantara 11. Jakarta: Perpustakaan Nasional Republik Indonesia bekerjasama dengan Pusat Studi Sunda.

Mamat Sasmita. 2015. "Ragam Hias dina Naskah Sanghyang Siksa Kandang Karesian." Manglé, no. 2514, 2515, 2516, February-March 2015.

Meijer, J.J. 1891. "Badoejsche Pantoenverhalen.” Bijdragen tot de Taal-, Land- en Volkenkunde van Nederlandsch-Indië 40: 45-105.

Meilink-Roelofsz, M.A.P. 1962. Asian Trade and European Influence in the Indonesian Archipelago between 1500 and about 1630. 's-Gravenhage: Martinus Nijhoff.

Mocquet, Jean. 1830. Voyage en Afrique, Asie, Indes orientales et occidentales. Paris: Imprimerie de Migneret.

Nina Maftukha, Yustiono, and Ira Adriati. 2017. "Visualisasi Tenun Baduy." Journal of Visual Art and Design 9 (2): 51-66. https://doi.org/10.5614/j.vad.2017.9.2.1.

Noorduyn, J., and A. Teeuw. 1999. "A Panorama of the World from Sundanese Perspective." Archipel 57 (Special issue: l'horizon nousantarien; mélanges en homage à Denys Lombard): 209-21.

—. 2006. Three Old Sundanese Poems. Bibliotheca Indonesica 29. Leiden: KITLV Press.

Pelras, Christian. 1972. "Contribution à la géographie et à l'ethnologie du métier à tisser en Indonésie." In Langues et techniques, Nature et Société, edited by Jacqueline M.C. Thomas and Lucien Bernot, 81-98. Paris: Klinksieck.

Pigeaud, Th.G.Th. 1960. Java in the 14th Century: A Study in Cultural History. The NāgaraKèrtāgama by Rakawi, Prapañca of Majapahit, 1365 A.D. 5 vols. Koninklijk Instituut voor Taal-, Land- en Volkenkunde Translation Series 4. The Hague: Martinus Nijhoff.

Pleyte, Cornelis Marinus. 1910. De legende van den Loetoeng Kasaroeng: een gewijde sage uit Tji-rebon. Verhandelingen van het Bataviaasch Genootschap van Kunsten en Wetenschappen 58. Batavia; 's Hage: Albrecht; Nijhoff.

—. 1911. De Inlandsche nijverheid in West-Java als sociaal-ethnologisch verschijnsel. Vol. 2. 3 vols. Batavia: Javasche Boekhandel \& Drukkerij.

Prijohoetomo. 1934. Nawaruci: inleiding, Middel-javaansche prozatekst, vertaling vergeleken met de Bimasoetji in oud javaansch metrum. Groningen: Wolters.

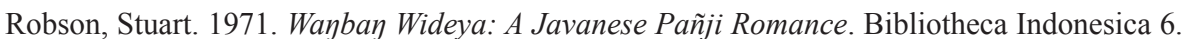
The Hague: Martinus Nijhoff. 
- 2015. The Old Javanese Rāmāyana: A New English Translation with an Introduction and Notes. Javanese Studies 2. Tokyo: Research Institute for Languages and Cultures of Asia and Africa, Tokyo University of Foreign Studies.

Soegeng Toekio. 1987. Mengenal Ragam Hias Indonesia. Bandung: Angkasa.

Tien Wartini, Mamat Ruhimat, and Aditia Gunawan. 2011. Sanghyang Swawarcinta: teks dan terjemahan. Jakarta: Perpustakaan Nasional Republik Indonesia \& Pusat Studi Sunda.

Undang Ahmad Darsa, and Edi Suhardi Ekadjati. 2004. "Sanghyang Raga Dewata." In Fatimah in West Java: moral admonitions to Sundanese gentlewomen dan Kajian lainnya mengenai Budaya Sunda, 134-79. Seri Sundalana 2. Bandung: Pusat Studi Sunda.

-. 2006. Gambaran Kosmologi Sunda (Kropak 420); Silsilah Prabu Siliwangi, Mantera Aji Cakra, Mantera Darmapamulih, Ajaran Islam (Kropak 421); Jatiraga (Kropak 422). Bandung: Kiblat Buku Utama.

Veldhuisen-Djajasoebrata, Alit. 1988. Weavings of Power and Might: The Glory of Java. Rotterdam; Toronto: Museum voor Volkenkunde; Museum for Textiles.

Wisseman Christie, Jan. 1993. "Texts and Textiles in 'Medieval' Java." Bulletin de l'École Française d'Extrême-Orient 80 (1): 181-211.

Zoetmulder, P.J. 1982. Old Javanese-English Dictionary. 2 vols. 's-Gravenhage: Martinus Nijhoff. 